\title{
Inspiração nos anos de chumbo Bastidores das reportagens vencedoras do Prêmio Esso durante a ditadura militar
}

\section{Inspiration from the leaden years Behind the scenes of the winning during the military dictatorship}

DOI: $10.46814 /$ lajdv3n4-060

Recebimento dos originais: 01/05/2021

Aceitação para publicação: 31/06/2021

\author{
Priscila Rossiter \\ Jornalista graduada pelo UniCEUB \\ Endereço: SQN 415 Bloco E apt 110 cep: 70878-050 \\ E-mail: priscila_rossiter@yahoo.com.br \\ Vivaldo Reinalto de Sousa \\ Mestre em Ciência Política \\ Instituição: UnB (Universidade de Brasília) \\ E-mail: vivaldo.sousa@ceub.edu.br
}

\begin{abstract}
RESUMO
Apesar das dificuldades enfrentadas pelo jornalismo durante o período do regime militar - de 1964 a 1985 - devido à censura, repórteres e editores continuaram a produzir boas matérias. Reportagens que mostram um país ainda com grande concentração de renda; o seqüestro no Brasil de opositores da ditadura militar instalada no Uruguai; como viviam os superfuncionários públicos ou como militares organizaram atentados para evitar a reabertura política do país. Este trabalho pretende discutir os bastidores de matérias que ajudaram a construir a história do Brasil em uma época marcada pela repressão. Em meio às mudanças no cenário brasileiro, o Prêmio Esso de Jornalismo completava nove anos em 1964. Criado pela empresa Esso Brasileira de Petróleo, com o aval da Associação Brasileira de Imprensa, o Prêmio tinha a intenção de reconhecer e valorizar os profissionais da Imprensa brasileira. Quando surgiu, a premiação causou certa estranheza entre os jornalistas, mas depois logo se tornou reconhecida entre os profissionais da área. Desde o começo, o Esso procurou fugir dos gêneros de reportagens considerados sucesso na década de 50, que eram aqueles relacionados ao sensacionalismo e à promoção pessoal. Os organizadores pretendiam reconhecer os trabalhos ligados ao interesse público. Na presente pesquisa, a abordagem teórico-metodológica usada foi a análise de conteúdo. Para isso, foram feitas entrevistas individuais e semi-abertas, realizadas entre setembro de 2006 e julho de 2007, com doze jornalistas ganhadores do Prêmio Esso de Jornalismo durante o regime militar. As entrevistas realizadas para este trabalho revelam as dificuldades encontradas, bem como as técnicas de apuração e a influência do Esso na vida dos jornalistas. Algumas das informações também foram recuperadas a partir de depoimentos já publicados dos autores das reportagens.
\end{abstract}

Palavras-chave: Jornalismo, Prêmio Esso, Regime Militar.

\begin{abstract}
Despite the difficulties faced by journalism during the period of the military regime - from 1964 to 1985 - due to censorship, reporters and editors continued to produce good stories. Reports that show a country still with a high concentration of income; the kidnapping in Brazil of opponents of the military dictatorship installed in Uruguay; how super public employees lived or how the military organized attacks to avoid the political reopening of the country. This work intends to discuss the behind-the-
\end{abstract}


scenes stories that helped construct the history of Brazil in an era marked by repression. Amidst the changes in the Brazilian scenario, the Esso Journalism Award completed nine years in 1964. Created by Esso Brasileira de Petróleo, with the endorsement of the Brazilian Press Association, the award intended to recognize and value the Brazilian Press professionals. When it first appeared, the award caused some strangeness among journalists, but it soon became recognized among professionals in the field. From the beginning, the Esso sought to get away from the genres of reportage considered successful in the 1950s, which were those related to sensationalism and personal promotion. The organizers intended to recognize work linked to the public interest. In the present research, the theoretical and methodological approach used was content analysis. To this end, semi-open individual interviews were conducted between September 2006 and July 2007 with twelve journalists who won the Esso Journalism Award during the military regime. The interviews conducted for this work reveal the difficulties encountered, as well as the reporting techniques and the influence of the Esso in the journalists' lives. Some of the information was also recovered from already published testimonies of the authors of the reports.

Keywords: Journalism, Esso Award, Military Regime.

\section{INTRODUÇÃO}

O ano era 1964. Meses antes do golpe militar que derrubaria o então presidente João Goulart, a reportagem Cem Dias na Amazônia de Ninguém levava o título de trabalho vencedor do Prêmio Esso de Jornalismo. O autor da série publicada no Jornal do Brasil, o repórter Walter Firmo - que depois ganhou destaque como um dos principais fotógrafos brasileiro -, passara cem dias viajando pela Amazônia. Lá, ele revelou uma região que ia além da exuberância: com 3,5 milhões de pessoas sendo assistidas por 28 médicos, um alto índice de analfabetismo e mortalidade infantil. Firmo denunciou a realidade de uma Amazônia que até então poucos conheciam.

Esta é apenas uma das 21 reportagens vencedoras do Prêmio Esso publicadas entre 1964-1985. Os bastidores dessas reportagens serão resgatados na presente pesquisa, a fim de mostrar que mesmo com várias limitações, os bons trabalhos continuaram a ser produzidos por diários como $O$ Estado de S. Paulo, Folha de S.Paulo, Jornal do Brasil, O Globo, Correio Braziliense, Jornal de Brasília e revistas como Realidade, Fatos e Fotos, IstoÉ e Veja.

Apesar do quadro que se configurou no país durante os 21 anos de autoritarismo, as grandes reportagens, tanto de cunho social quanto político, continuaram a fazer parte da história do jornalismo brasileiro. E foi principalmente nessa época que o jornalismo investigativo ganhou força no meio: os jornalistas começaram a buscar uma verdade antes desconhecida por parte dos brasileiros.

Nos Estados Unidos, o reconhecimento do jornalismo investigativo pela imprensa se dá, segundo Bill Kovach e Tom Rosenstiel (2003, p. 169), em 1964, quando o Philadelphia Bulletin ganha o Prêmio Pulitzer com uma série de reportagens sobre corrupção na polícia local. No entanto, vários autores não conseguiam ver o jornalismo investigativo como uma categoria jornalística. 
O termo "jornalismo investigativo" foi muito criticado por diversos profissionais da área. Ainda assim, esse ramo do jornalismo ganhou destaque não só nos Estados Unidos e na Europa, mas também em países como o Brasil. A busca pela notícia de interesse público - princípio que sempre deveria ter norteado o trabalho dos jornalistas - começou a tomar conta das redações e de quem produzia as reportagens, deixando de lado o jornalismo baseado em notas oficiais.

De acordo com Dirceu Fernandes Lopes e José Luiz Proença (2003, p. 10), o jornalismo investigativo baseia-se em dois pontos fundamentais: "a busca da verdade oculta e juntar os cacos da realidade e estabelecer relações entre eles".

O Prêmio Esso existe desde 1955. Nesses 52 anos, mais de 20 mil trabalhos foram premiados em diversas categorias: informação científica, fotografia, telejornalismo, charge, ecologia, entre outros. Algumas dessas categorias surgiram apenas ao longo do tempo: hoje são 15 prêmios fixos.

Nove anos após a criação do Esso viria o golpe responsável pela censura e repressão. Inicialmente, grande parte dos veículos de comunicação apoiou a queda do governo do presidente João Goulart, em 1964. No entanto, com a posse do general Humberto de Alencar Castelo Branco, em 11 de abril de 1964, o governo adotou medidas para restringir a liberdade de expressão e, por isso, as empresas de comunicação passaram aos poucos a se afastar do governo militar. Com o distanciamento, a imprensa pôde explorar, na prática, o conceito de "quarto poder", isto é, de fiscalizadora dos poderes Executivo, Legislativo e Judiciário, mesmo com censores instalados nas redações do país - a partir de 1968.

O objetivo geral da pesquisa é mostrar como foram produzidas algumas das grandes reportagens jornalísticas publicadas durante o regime militar e, assim, ajudar na preservação da memória do jornalismo brasileiro, além de contribuir na formação dos estudantes da área. Para isso, o trabalho busca os seguintes objetivos específicos:

a) Identificar as principais técnicas de apuração jornalísticas usadas nas doze reportagens selecionadas entre as 21 vencedoras do Prêmio Esso de 1964 a 1985;

b) Com base nos temas abordados, mostrar como a pauta foi elaborada e quais as dificuldades para a apuração, edição e publicação da reportagem, já que, durante parte do regime militar, os censores se instalaram dentro das redações;

c) Verificar se a produção dessas reportagens mudou de alguma forma os rumos profissionais dos seus autores, porque alguns jornalistas foram ameaçados de morte em função de trabalho que reportagens que investigaram arbitrariedades praticadas pelos governantes do período. 
Nesta pesquisa, a abordagem teórico-metodológica usada será a análise de conteúdo. Para isso, foram realizadas entrevistas em profundidade com dez vencedores do Prêmio Esso, além da recuperação de depoimentos de outros, registrados em livros. As entrevistas, realizadas entre setembro de 2006 e julho de 2007, foram individuais e semi-abertas. Segundo Jorge Duarte (2005, p. 67), “a vantagem desse modelo é permitir criar uma estrutura para comparação de respostas e articulação de resultados, auxiliando na sistematização das informações fornecidas por diferentes informantes".

A pesquisa trata primeiramente do contexto histórico do Brasil no período em que as reportagens foram apuradas e escritas, e aborda o surgimento do Prêmio Esso, ainda na década de 50. No capítulo seguinte, o trabalho traz a diferença entre o jornalismo feito no século XXI e aquele praticado nos anos de regime militar. Em seguida, os bastidores das reportagens serão resgatados, a fim de mostrar as técnicas e métodos usados pelos jornalistas nas matérias e o que há em comum entre elas.

\section{O GOLPE E O ESSO}

O golpe militar de 1964, implantado com a justificativa de livrar o país do comunismo e resgatar a democracia, tomou um rumo que muitos brasileiros não imaginavam. O que era para ser apenas um episódio transitório ganhou grandes proporções e estendeu-se por mais de vinte anos.

Nesse período, entre outras medidas, foram adotados decretos - chamados de Atos Institucionais - que limitavam a liberdade dos cidadãos. A restrição à democracia iniciou-se tão logo o general Humberto de Alencar Castelo Branco, primeiro presidente após o golpe de 64, assumiu o poder.

Com a saída de João Goulart, Castelo Branco instituiu a "democracia restringida", por meio do Ato Institucional 1, baixado em abril de 1964. O AI-1 limitava a atuação do Congresso Nacional, permitia a cassação de mandatos de parlamentares e suspendia direitos políticos por um prazo de até dez anos. Este era apenas o início de medidas que seriam tomadas ao longo do regime autoritário.

As mudanças ocorreram também no que diz respeito aos partidos políticos. Aqueles que preexistiam ao Golpe - entre os quais vale citar, PCB (Partido Comunista Brasileiro), que já havia tido o registro cassado em 1947; UDN (União Democrática Nacional); PTB (Partido Trabalhista Brasileiro) e PSD (Partido Social Democrático) - foram extintos. Com o decreto do AI-5, em 13 de dezembro de 1968, o governo instituiu o bipartidarismo: de um lado estava o governo, com a Aliança Renovadora Nacional (Arena); do outro, o Movimento Democrático Brasileiro (MDB), representando a oposição consentida.

Em meio às mudanças no cenário brasileiro, o Prêmio Esso de Jornalismo completava nove anos em 1964. O Prêmio, criado pela empresa Esso Brasileira de Petróleo com o aval da Associação 
Brasileira de Imprensa, tinha a intenção de reconhecer e valorizar os profissionais da Imprensa brasileira. Quando surgiu, a premiação causou certa estranheza entre os jornalistas; as entregas dos prêmios eram marcadas por almoços e reuniões discretas. Em 1955, os primeiros e únicos vencedores foram os jornalistas da revista $O$ Cruzeiro Ubiratan de Lemos e Mário de Moraes, com a reportagem Uma Tragédia Brasileira: os paus-de-arara.

Desde o começo, o Esso procurou fugir dos gêneros de reportagens considerados sucesso na década de 50, que eram aqueles relacionados ao sensacionalismo e à promoção pessoal. Os organizadores pretendiam reconhecer os trabalhos ligados ao interesse público. Três anos antes do golpe militar, em 1961, foi criado o Prêmio Esso de Fotografia. A partir daí, com as transformações e os avanços tecnológicos, outras categorias foram acrescentadas, entre elas Informação Econômica, Informação Científica e Informação Esportiva. Com o Prêmio Esso, diversos jornalistas tornaram-se conhecidos e, mais que isso, deram espaço às grandes reportagens de cunho social e político.

Em 1967, o general Artur da Costa e Silva assume o poder. Com características bem diferentes de Castelo Branco, Costa e Silva nada lembrava o estilo intelectualizado do primeiro: além de preferir atividades leves, era visto como a esperança da linha dura e de nacionalistas autoritários, já que os militares andavam descontentes com a política de Castelo Branco, de aproximação com os Estados Unidos e abertura aos capitais estrangeiros. (FAUSTO, 2002, p. 476.)

Apesar da repressão e autoritarismo da época, tanto no período Castelo Branco quanto no de Costa e Silva um grupo de cerca de oito jornalistas era chamado, de dois em dois meses, para conversas informais. Entre eles estava Carlos Chagas, que mais tarde se tornaria porta-voz de Costa e Silva, e seria também vencedor do Prêmio Esso em 1970, com a série de reportagens 113 Dias de angústiaimpedimento e morte de um presidente, nas quais relata o período de doença do general.

Quando, em 1968, Costa e Silva baixou o AI-5, as reuniões periódicas entre governo e imprensa foram interrompidas, o Congresso foi fechado e os meios de comunicação passaram a sofrer, na prática, a censura.

Um ano após a instalação do AI-5, Costa e Silva sofre um derrame. Sem possibilidade de recuperação, ocorre um golpe: a instalação de uma junta militar decide pelo general Emílio Garrastazu Médici, no lugar do vice Pedro Aleixo para assumir o governo. Tendo como vice o ministro da Marinha, o governo Médici ajudou a acomodar os interesses de todos.

Foi durante o governo Médici que o país viveu o chamado "milagre econômico", quando o PIB (Produto Interno Bruto) cresceu em média de 11\% entre 1968 e 1973. Aproveitando esse cenário, as propagandas a favor do governo se encarregaram de neutralizar a realidade que o país vivia. 
Mas foi também durante o governo do general que a repressão e a censura ganharam força. $\mathrm{O}$ jornalista Evandro Carlos de Andrade conta, por exemplo, que a polícia tinha o costume de entrar nas redações e ler o jornal inteiro antes de cada publicação. Isso se deu a partir de 1972.

A censura (...) se agravou muito a partir de 72. Foi quando ela se tornou pesada. Então eram aquelas proibições nunca escritas, porque era uma hipocrisia. Ia um agente da Polícia Federal, entrava na redação e dizia assim: 'Assunto tal, assunto tal, assunto tal não pode dar'. Muitos desses assuntos nós ficávamos sabendo pela proibição, porque era assim que se exercia. Mas por quê? Porque eles não queriam registro histórico - o que é uma loucura, imaginar que não houve censura. Sobre a censura, há testemunho exaustivo de todos quantos foram censurados. (ANDRANDE in DINES, FERNANDES JR., SALOMÃO, 2000, p. 257)

Mesmo com o início da abertura política, após o presidente Ernesto Geisel ter tomado posse, em 1974, a censura prévia ainda fazia parte das redações. Com a abertura, definida pelo governo como "lenta, gradual e segura", os veículos de comunicação continuaram a sofrer com a repressão, mas, paulatinamente, ela se tornava cada vez mais frágil. Em 1975, por exemplo, a censura de $O$ Estado de S. Paulo, grande opositor do regime militar, foi suspensa. Segundo Boris Fausto (2002, p. 490), de um lado, o presidente tentava equilibrar a pressão vinda da linha-dura do regime, ao mesmo tempo em que "desejava controlar a abertura, no caminho de uma indefinida democracia conservadora, evitando que a oposição chegasse muito cedo ao poder”.

No curso de 1975, Geisel combinou medidas liberalizantes com medidas repressivas. As últimas eram destinadas a acalmar o "público interno", ou seja, integrantes da corporação militar. No mês de janeiro, tivemos exemplos dessa tática: em surdina, o governo suspendeu a censura ao jornal $O$ Estado de S. Paulo; a isto se seguiu uma ousadia maior dos outros jornais, com destaque para a Folha de S.Paulo. (FAUSTO, 2002, p. 491)

Ainda assim, o confronto entre a linha-dura e a sociedade civil continuava, bem como as torturas e o "desaparecimento" de pessoas pela repressão. Um caso que marcou época e até hoje é lembrado é o do jornalista Vladimir Herzog, diretor de jornalismo da TV Cultura e "suspeito de ter ligações com o PCB”, segundo o historiador Boris Fausto. Intimado pelo órgão criado nos anos de regime militar e responsável pela repressão política, DOI-CODI (Destacamento de Operações de Informações - Centro de Operações de Defesa Interna), em 1975, Herzog foi morto em São Paulo. Segundo o governo, o diretor da TV Cultura havia cometido suicídio por enforcamento. Na realidade, Herzog foi torturado até morrer.

Seguindo o caminho de abertura política, o general João Batista Figueiredo assume a presidência em 1979, no lugar de Ernesto Geisel. Chefe do SNI durante o governo de Geisel, Figueiredo serviu a todos os generais-presidentes que o antecederam, apesar das divergências entre eles. Como presidente, Figueiredo promoveu a anistia política e extinguiu o bipartidarismo que vigorou durante o regime militar: a Arena converteu-se em Partido Democrático Social (PDS) e o MDB em Partido do 
Movimento Democrático Brasileiro (PMDB). Novos partidos foram criados, entre eles o Partido dos Trabalhadores (PT), fruto do nascente movimento sindical, cuja melhor expressão pode ser identificada no Sindicato dos Metalúrgicos do ABC.

No entanto, essas mudanças não significavam que o Brasil estivesse completamente livre dos atos da linha-dura que marcaram a década de 70. Assim como Geisel, Figueiredo também enfrentou ações da ala mais radical do governo, como bombas colocadas em jornais e sequiestros de figuras ligadas à Igreja.

Os atos culminaram com a tentativa de explodir bombas no centro de convenções do Riocentro, a 30 de abril de 1981. Aí se realizava um festival de música, com a presença de milhares de jovens. Uma das bombas não chegou a ser colocada. Explodiu no interior de um carro, ocupado por um sargento e um capitão do Exército; o sargento morreu no local e o capitão ficou gravemente ferido. A outra bomba explodiu na casa de força do Riocentro. O governo conduziu um IPM que confirmou uma absurda versão dos fatos, isentando os responsáveis. Para tanto, chegou ao ponto de substituir um coronel que vinha realizando uma investigação séria. $\mathrm{O}$ pedido de demissão de Golberi da chefia da Casa Civil, em agosto de 1981, teve certamente a ver com a manipulação do inquérito. (FAUSTO, 2002, p. 505)

As explosões tiveram ampla repercussão na mídia. Os impressos Jornal do Brasil e $O$ Estado de S. Paulo publicaram séries de reportagens que desmontavam o relatório oficial do inquérito, o que rendeu aos diários, o prêmio principal e o de reportagem do Esso, respectivamente.

Figueiredo deixou o governo em 1985. Depois de mais de vinte anos de regime militar, já desgastado e desacreditado, forma-se um clima propício no país para a introdução da democracia: a campanha pelas eleições diretas para a presidência da República ganhou as ruas a partir de uma emenda apresentada pelo então deputado federal Dante de Oliveira, do PMDB de Mato Grosso. As manifestações populares, chamadas de Diretas-Já, tiveram início em novembro de 1983. A pressão de grande parte dos brasileiros e da imprensa foi essencial para o retorno à democracia. Apesar disso, as amarras constitucionais impediam as eleições diretas, e para que a Constituição fosse alterada era preciso que dois terços do Congresso votassem a favor do retorno ao direito de os brasileiros escolherem diretamente o presidente da República. O desejo da maioria da população por eleições diretas, entretanto, foi derrotado por 22 votos: 298 foram a favor de eleições diretas, mas para a emenda ser aprovada eram precisos 320 votos. Com a derrota da emenda pelas eleições diretas, o PMDB lançou a candidatura de Tancredo Neves no Colégio Eleitoral. Com o apoio de parte do PDS, abrigada na Frente Liberal, José Sarney foi lançado vice de Tancredo. Mesmo depois da derrota da emenda, em 1985, o candidato Tancredo Neves saiu vencedor no colégio eleitoral, órgão ao qual se atribuiu a tarefa de escolher o novo presidente. 
Embora eleito, Tancredo não assumiu o cargo: por problemas de saúde, precisou ser internado um dia antes de sua posse. Seu substituto, José Sarney, assume como presidente provisório. Chegava ao fim, então, mais uma etapa da história brasileira, marcada pela repressão.

\section{JORNALISMO, “GRITOS" E SILÊNCIO}

Se a investigação deveria ser a alma do jornalismo - fosse qual fosse o sufixo (político, econômico, etc.) -, o fato é que com as redações cada vez mais enxutas e profissionais cada vez mais sobrecarregados, o jornalismo diário no Brasil vem sendo gradativamente reduzido a um relato nu e cru das declarações e dos fatos que aconteceram no dia anterior. $\mathrm{O}$ jornalismo brasileiro praticado por jornais, rádios e televisões é essencialmente uma história do ontem. (GRAMACHO, 2006, p. 254).

O jornalismo que se vê hoje nas redações é, em parte, diferente daquele da década de 60 . A primeiro vista, é possível perceber a mudança quantitativa. As redações ficaram mais "enxutas" - há menos jornalistas trabalhando nelas. Um dos motivos para essa diminuição está ligado aos cortes de despesas que as empresas de comunicação tiveram que realizar nos últimos anos.

Apesar da diminuição de profissionais, o jornalista tem hoje a chance de ter um único emprego. Diferentemente do que ocorria nos anos 60, o jornal pode ser hoje a principal ocupação ou fonte de renda.

Outra diferença fundamental diz respeito ao tempo gasto na apuração de pautas. Os jornalistas, além de trabalharem mais, precisam saber - de forma nítida - o que é realmente importante para a publicação do dia seguinte - no caso dos jornais impressos -, ou para as notícias que vão ao ar no mesmo dia - quando se trata de rádio, TV e internet.

A internet acirrou ainda mais a competição dos meios de comunicação: a realidade do "quem dá a notícia antes" passou a ser o imperativo em grande parte dos casos. A mercadoria - a notícia deve ser vendida, repassada o mais rápido possível a fim de saciar a curiosidade do leitor, telespectador ou ouvinte.

A chegada da tecnologia às redações trouxe também benefícios para quem trabalha diretamente com a notícia. A partir dos instrumentos oferecidos pela tecnologia de ponta, o jornalista pôde explorar mais uma ferramenta: a de organizar e interpretar dados estatísticos, podendo então, investir em matérias baseadas nessas informações.

Devido à pressa dos profissionais nas redações e pela falta de tempo e espaço no jornal, a apuração e a publicação de reportagens investigativas tornaram-se menos freqüentes. Isso, de certa maneira, impede que o jornalista tenha disponibilidade para se dedicar à investigações, o que não quer dizer, porém, que elas não façam parte dos veículos de comunicação. 
Levando-se em conta que os veículos continuam reservando espaço para as reportagens investigativas, vale ressaltar que elas não são necessariamente resultado de investigações do próprio jornalista; as informações podem ter sido pesquisadas por terceiros, como Ministério Público, polícia etc. Nesses casos, cabe ao jornalista relacionar e divulgar o que é de relevância. Mas tal tipo de matéria, baseada somente no trabalho de terceiros, não pode ser definida como jornalismo investigativo.

De acordo com Gramacho (2006, p. 254), o jornalista investigativo possui três formas de buscar informações das quais necessita e que contribuem no processo de apuração: públicas, privadas e sigilosas.

As informações públicas são, como o próprio nome diz, acessíveis a todos - ainda que possa custar muito juntá-las para montar o quebra-cabeças de uma apuração. Na corrida por um "furo", um repórter pode colocar seu jornal à frente da concorrência se souber usar com agilidade essas fontes de informações públicas. Em seguida, estão as informações privadas, histórias orais e documentos que pertencem a pessoas físicas e aos quais normalmente só se pode chegar com a aquiescência de seus proprietários (algo fácil quando eles próprios têm interesse na divulgação, mas muito difícil em caso contrário). Em terceiro lugar, estão as informações sigilosas, normalmente documentos protegidos por sigilos bancário, fiscal e telefônico. Com sorte ou com muito trabalho é possível chegar até eles.

Apesar da dinâmica predominante hoje nas redações e da sobrecarga imposta aos repórteres, os profissionais contam com um fator determinante para a prática do jornalismo: a liberdade que se tem para apurar, checar e denunciar aquilo que é necessário e de interesse público. Ou seja, parte da imprensa tem a legitimidade de - e para - cumprir o papel de atuar como uma espécie de "quarto poder". Esse quadro não se configura em toda a imprensa, pois há um outro fator predominante hoje em dia, que é a competição entre jornalistas e veículos de comunicação. A concorrência acaba, muitas vezes, colocando em pauta determinados assuntos.

A liberdade de expressão existente permite aos profissionais trabalhar com uma série de recursos antes proibidos pelo autoritarismo imposto entre 1964 e 1985: o contato maior com as fontes e também liberdade para criticar, apoiar ou denunciar quem quer que seja. Como afirma Traquina (1999), com o quarto poder, “a defesa e vigilância da nova força chamada 'opinião pública' é invocada como dever". A imprensa seria, portanto, uma fiscalizadora dos poderes Executivo, Legislativo e Judiciário.

Assim como as matérias especiais feitas hoje, baseadas em grandes histórias, as reportagens publicadas durante o regime militar priorizaram não só boas narrativas ou personagens, mas se destacaram também pelo rigor na investigação e apuração dos fatos. Prova disso, são as vencedoras do mais importante prêmio ligado ao jornalismo no país - o Prêmio Esso de Jornalismo. 
Durante o regime militar foram 21 trabalhos ganhadores. Em 1966, o prêmio não foi concedido. A maior parte das premiadas do Esso tinha a política como principal tema abordado e as revistas e jornais vencedores se concentravam no eixo Rio-São Paulo (MACEDO, 2006, p. 10).

Dentre as reportagens vencedoras que tratavam de política, uma pode ser considerada destaque: Como vivem nossos superfuncionários, de O Estado de S. Paulo, escrita pelo jornalista Ricardo Kotscho durante o governo do general Ernesto Geisel. A matéria, publicada em 1976, denunciou as mordomias dos funcionários públicos de vários estados, mas principalmente da capital, bancadas pelo governo na época do regime militar. Foi a partir daí que o termo "mordomia" entrou para o vocabulário político do país.

Mesmo tendo a denúncia como foco, o jornalismo investigativo, para Dines, não é necessariamente aquele feito para denunciar escândalos. É preciso analisar, interpretar e relacionar os fatos, tendo como objetivo fornecer a notícia de maneira mais responsável ao leitor.

O jornalismo investigativo não é apenas jornalismo de sensações ou de escândalos. Relacionase com o jornalismo interpretativo ou analítico, pois, ao inquirir sobre causas e origens dos fatos, busca também a ligação entre eles e oferece a explicação da sua ocorrência. Ao praticálo, necessariamente, não se obriga a postura de denúncia. Ele pode comportar uma atitude grave, estudiosa e, sobretudo, responsável. E desde que o jornalista adote o princípio filosófico de que qualquer questão oferece duas perspectivas - uma pró e outra contra - e entenda que a boa reportagem é justamente aquela que consegue apresentá-las com eqüidistância, manter-seá a objetividade e um bom padrão ético. (DINES, 1996, p. 92)

$O$ Estado de S. Paulo é um bom exemplo de como um jornal, ao passar por uma censura mais dura, pode encontrar maneiras de se esquivar das proibições a que vinha sendo submetido. O diário, em vez de aceitar pacificamente aquilo que lhe era imposto, inovou: com a publicação de poemas e receitas culinárias no lugar de notícias censuradas, o impresso provou que era possível burlar os censores instalados nas redações. Inicialmente, porém, os leitores do diário não compreendiam o sentido daqueles textos, como pôde verificar Oliveiros Ferreira, que era quem escolhia os poemas. A partir daí, O Estado de S. Paulo teve a idéia de repetir versos de um mesmo autor, sempre que as reportagens sofressem censura, a fim de que os leitores do jornal captassem o real motivo daquelas publicações.

A partir de 19 de julho de 1973, quando foi proibido noticiar a volta ao país do compositor Geraldo Vandré, os versos em sequiência de Os Lusíadas, de Camões, passaram a ser o sinal de que uma matéria fora censurada. Outros expedientes também foram utilizados, mas Camões tornou-se um alerta inconfundível. (ABREU, 2003, p. 289)

Como afirma Dines (1996, p. 135), a decisão de O Estado de S. Paulo, em publicar poesias ou receitas culinárias no lugar das matérias proibidas pela censura, "é a melhor demonstração de como esta é intrinsecamente falha, superável e pouco inteligente". 
Outro jornal que usou a tática de denunciar a censura por meio de versos e frases com duplo sentido foi o Jornal do Brasil. Em 14 de dezembro de 1968, um dia depois do decreto do AI-5, o diário publicou na primeira página a famosa previsão: “Tempo negro. Temperatura sufocante. $\mathrm{O}$ ar irrespirável. O país está sendo varrido por fortes ventos...”. (ABREU, LATTMAN-WELTMAN e ROCHA, 2003, p. 97)

\subsection{CENSURA}

O Brasil foi vítima da censura em dois momentos distintos. O primeiro ocorreu no governo de Getúlio Vargas, durante o Estado Novo, entre 1937 e 1945. Neste período, segundo Bernardo Kucinski (1998, p. 60), se estabeleceu "um sistema oficial regular e amplo de censura”. Foi nessa época que surgiu o DIP (Departamento de Informação e Propaganda).

O segundo momento da censura tornou-se realidade após o golpe de 64 no qual o então presidente João Goulart foi derrubado. Maria Aparecida de Aquino (1999, p. 205) afirma que, nesses dois períodos, a censura política ocorreu "de forma contínua, exercida de maneira constante".

A censura aos meios de comunicação teve início com o golpe militar e foi "lentamente sendo institucionalizada", de acordo com Aquino. Mas foi a partir de 13 de dezembro de 1968, com a edição do AI-5, que a situação tornou-se crítica. Além da repressão física, jornalistas foram submetidos à censura nas redações.

De 1968 a 1978, a imprensa escrita sofreu duas formas de censura política, segundo Aquino: por meio de telefonemas, que podiam ser anônimos ou não, e por ordens escritas encaminhadas aos jornais. Outra maneira da censura se fazer presente foi por meio de acordos firmados entre proprietários de meios de comunicação e militares. Os donos de veículos impressos passavam, inclusive, por pressões econômicas.

Ao mesmo tempo em que a censura se fazia presente na imprensa, os jornalistas passaram a se posicionar de maneira mais crítica e criativa. Na fase de consolidação do autoritarismo, a partir do AI5, vários deles foram demitidos, já que não aceitavam pacificamente o quadro instalado pelos militares. Foi o caso da equipe responsável por capas de tortura da revista Veja. Em 1969, todos eles foram substituídos por outros jornalistas.

Kucinski (1998, p. 56) considera que, durante o regime militar, o controle da informação passa por quatro fases distintas: a primeira, de 1964 a 1968, ainda contava com a autonomia dos profissionais da imprensa, que se manifestavam de modo crítico diante dos acontecimentos; o período que vai de 1968 a 1972, quando surgem duas imprensas no país - a oficial e a alternativa - e com a substituição de equipes nos veículos de comunicação; de 1972 a 1975, período marcado pela autocensura nas 
redações; e a última fase caracterizada pela liberalização da imprensa para intimidar a "linha-dura" do regime.

\subsection{AUTOCENSURA}

A ditadura militar e conseqüentemente a censura prévia deixaram uma série de resquícios nos profissionais de comunicação. Um deles é a autocensura, caracterizada pela restrição à liberdade do indivíduo, que se torna vítima da própria repressão.

O jornalista que se autocensura é a primeira e principal vítima da autocensura. A censura exógena do Estado impede o exercício da liberdade, sem necessariamente afetar sua dignidade de ser humano e sua personalidade de homem livre. Já a autocensura atinge diretamente a integridade do ser, porque ele aceita a restrição à sua liberdade e se torna, ao mesmo tempo, agente e objeto da repressão. (KUCINSKI, 1998, p. 68).

Segundo Kucinski (1998, p. 56), a autocensura teve início antes mesmo do golpe instalado em 1964: os "barões da imprensa", que participaram ativamente da conspiração, tinham um objetivo específico dentro do golpe - o de derrubar o jornal Última Hora, que crescia nas grandes capitais ao mesmo tempo em que promovia um discurso divergente daquele dominante. Assim, os barões deixavam de denunciar o golpe, isto é, promoviam a autocensura, já que tinham conhecimento do que estava sendo planejado, mas nada faziam.

Ao contrário da censura prévia, que é instável e imprevisível, pode-se afirmar, em um primeiro momento, que a autocensura não cria prejuízos econômicos. O confisco, por exemplo, de uma matéria de capa, acarretaria ao veículo problemas de natureza estratégica e financeira: como seria feita a substituição de uma matéria por outra em um curto espaço de tempo; quanto à questão de tamanho da reportagem, etc. De acordo com Kucinski (1997, p. 61), “a autocensura não afetava o modo de produção da grande imprensa, ao contrário da censura permanente e severa aplicada aos jornais alternativos".

Como se verá a seguir, os 21 anos de regime militar não foram só de censura e repressão. Nesse período, reportagens importantes foram produzidas e publicadas, superando e desafiando o autoritarismo da época. Graças à coragem, insistência e ao rigoroso processo de apuração, diversos repórteres conseguiram derrubar as barreiras impostas pelo então governo.

\section{4 "UM FOCA PERDIDO NA SELVA" - REPORTAGENS VENCEDORAS DO PRÊMIO ESSO DE JORNALISMO ENTRE 1964 E 1984}

Extremo norte do Mato Grosso. Era o ano de 1972. Longe da metrópole, recém-casado, com 22 anos de idade, José Marqueiz vivia uma realidade totalmente diferente daquela a que estava acostumado. A rotina incluía se alimentar de peixes, macacos e formigas, dormir em rede e às vezes 
em barraca aberta - sem qualquer proteção - em um calor de mais de $40^{\circ}$, e tomar banho ao lado de jacarés. Mal sabia ele que, passados dois anos desta "aventura", sua vida daria uma reviravolta, graças ao Prêmio Esso, que ganharia em 1973. (Ver apêndice A e B)

José Marqueiz era apenas o que em Jornalismo se chama de foca. Um iniciante na profissão. Apesar da pouca idade, ele havia sido escolhido pelo jornal em que trabalhava na década de 70, $O$ Estado de S. Paulo, para cobrir a expedição dos índios Kranhacãrore, também conhecidos como "índios gigantes". Era a primeira vez que iria participar de uma missão como esta. Antes disso, ele produziu reportagens casuais sobre os índios tupi-guarani, que viviam na Barra do Uma, em São Sebastião (SP), e também no Litoral Norte de São Paulo. Além disso, havia passado também pelo Parque Nacional do Xingu e Serra do Cachimbo.

Portando duas máquinas fotográficas e um gravador - que nunca chegou a usar, "uma vez que o Cláudio, o cérebro da expedição, se negava a dar qualquer declaração diante de um gravador", segundo José Marqueiz, ao chegar às margens do rio Peixoto de Azevedo, o foca encontrou já acampados Cláudio Villas-Boas; jornalistas; e índios de diversas tribos xinguanas, escolhidos para integrar a expedição.

Os irmãos sertanistas Cláudio e Orlando Villas-Boas eram os responsáveis pela expedição dos índios Kranhacãrore - os últimos indígenas considerados totalmente primitivos, sem nenhum contato com a civilização. Os sertanistas desenvolviam o trabalho de contribuição à causa do índio brasileiro há três décadas. Durante dois anos - em 1972 e 1973 -, os Villas-Boas dedicaram-se a “impedir o atrito dos índios com efetivos do $9^{\circ}$ Batalhão de Engenharia de Construção do Exército, engajados na obra da rodovia Cuiabá-Santarém”. (BELOCH e FAGUNDES, 2006, p. 68)

No acampamento, Marqueiz percebia que os outros repórteres nutriam um certo desprezo por ele, pelo fato de ser apenas um iniciante na profissão. Graças ao isolamento do jornalista em relação aos outros colegas, Marqueiz decide juntar-se a Cláudio Villas-Boas. O sertanista passava boa parte do tempo fazendo anotações em um caderno.

Ao começar a ler o "diário", percebi a riqueza daquele documento como testemunho de uma ação anônima e heróica - vencendo as piores adversidades da natureza, mas sem nunca machucar ou prejudicar um índio sequer. E, com base nesse diário, que Claudio gentilmente me cedeu e autorizou a publicar, que construí a série de reportagens que intitulei Expedição de Contactação dos Índios Kranhacãrore para inscrever no Prêmio Esso, mas que saiu publicada como No Encalço dos Índios Gigantes. (MARQUEIZ em entrevista a autora)

O repórter de $O$ Estado de S. Paulo permaneceu no Rio Peixoto, no norte do Mato Grosso, por algumas semanas, mas segundo ele, não é possível calcular precisamente o tempo em que ficou na região. Após esse período e sem resultados da aparição dos índios gigantes, Marqueiz volta para Cuiabá e, em seguida, para a sucursal do diário em Santo André, no ABC, onde trabalhava. 
De volta à sucursal, já com o diário de Villas-Boas datilografado, Marqueiz mostra o material ao então secretário de redação do jornal, Oliveiros S. Ferreira, responsável por autorizar a publicação diária da série.

Quando recebeu a notícia de que os índios gigantes estavam prestes a estabelecer contato com os irmãos Villas-Boas, Marqueiz retorna à expedição, no início de 1973.

Acaso ou sorte, e já cansado da rotina de espera, o jornalista passava parte de seu tempo fazendo longas caminhadas pela região. Em um desses passeios, a Polícia Federal aparece no Rio Peixoto, a mando do general Médici, e retira todos os jornalistas do local. Ao voltar para o acampamento, Marqueiz se dá conta de que o avião que tinha visto sobrevoando o rio não era responsável por abastecer o local com alimentos, mas sim o que levara todos os seus colegas de volta à metrópole. "E não demorou nem uma hora para que os índios reaparecessem do outro lado do rio (eles haviam aparecido uma primeira vez, mas furtivamente)", conta o jornalista. Essa última matéria foi escrita, de acordo com Marqueiz, em menos de 40 minutos, "sob o impacto do acontecimento". A dificuldade, no entanto, foi enviar a reportagem à sucursal de $O$ Estado de S. Paulo.

\begin{abstract}
Tive dificuldade em enviar a matéria sobre o encontro final dos Villas-Boas com os Índios. Como eu tinha um avião Cesnna à minha disposição (para os federais esse avião era para uso dos Villas Boas), assim que escrevi a matéria (sentado no chão, com a máquina portátil sobre as pernas) peguei o avião e fui para Cuiabá. Lá, passei na Sucursal do Estadão e enviei o texto, via telex (o mais rápido meio de comunicação da época). Fui então para o aeroporto, mas os vôos para São Paulo estavam lotados. Precisava enviar os filmes de qualquer maneira (...). Por sorte - e que sorte! - interpelei um cidadão, que estava na fila de embarque, e perguntei se ele poderia levar o filme para São Paulo. Ele concordou. Telefonei, então, imediatamente para a Matriz e falei com o Raul - dei detalhes de como o homem estava vestido etc. Era sexta-feira à noite e, se o vôo não atrasasse, ainda daria para soltar a reportagem com foto na edição de sábado. Não deu outra. No sábado, o Estadão estampava com exclusividade a chamada na primeira página da reportagem narrando o encontro dos índios com os Villas-Boas, com uma foto. (MARQUEIZ em entrevista à autora)
\end{abstract}

Baseada no diário, a série de reportagens foi vencedora do Prêmio Esso de 1973. Como vencedor do Esso, José Marqueiz recebeu convites dos mais variados e importantes órgãos de comunicação do país. Ainda assim, rejeitou todos eles. Depois de uma passagem pelo Jornal do Brasil e $O$ Globo, o jornalista decidiu seguir a carreira em Assessoria de Imprensa.

Assim como José Marqueiz, o jornalista Ricardo Kotscho recebera instruções do diretor de redação do jornal $O$ Estado de S. Paulo. A intenção era produzir série de reportagens inspiradas na matéria de um correspondente do jornal americano The New York Times em Moscou, sobre os superfuncionários do governo comunista na ex-União Soviética.

A tese do diretor de $O$ Estado de S. Paulo, Fernando Pedreira, era que graças à censura aos meios de comunicação no Brasil, o governo formara um poder paralelo ao existente, no qual gastavase o dinheiro público a fim de sustentar uma nova classe tecnocrático-militar. 
Cabia, agora, ao jornalista buscar essas informações e confirmar ou refutar a idéia de Pedreira. Com a ajuda de um colega, Kotscho traduziu a extensa matéria e iniciou a pesquisa para a série de reportagem, que levaria quatro meses para ficar pronta, entre apuração e publicação.

Por meio de um deputado da oposição, Roberto Saturnino Braga, Ricardo Kotscho ficara sabendo onde e como poderia conseguir mais informações sobre as farras dos funcionários do governo: no Diário Oficial da União, nas publicações sob a rubrica "mordomias".

As farras eram das mais diversas. Desde sessões privadas de cinema com filmes censurados pelo governo, entre eles Último Tango em Paris e Laranja Mecânica, a longas listas de comes-e-bebes das melhores marcas estrangeiras. Os superfuncionários não mediam esforços para ter todo o conforto que achavam necessário. $\mathrm{Na}$ lista dos que tiravam proveito do dinheiro público estava o ministro do Trabalho, Arnaldo Prieto, cujo número da criadagem fixa chegava a 28 empregados.

Devido à importância e alto grau de combustão do assunto, ao conversar com as fontes Kotscho não revelava o verdadeiro motivo da apuração. Inicialmente, ele dizia que estava preparando uma matéria sobre os hábitos e comportamento das pessoas que viviam em Brasília. À medida que o número de informações aumentava, algumas fontes foram informadas sobre o verdadeiro motivo da reportagem, segundo entrevista concedida à autora em 7 de setembro de 2006.

No processo de apuração, Kotscho contou com a ajuda de 40 repórteres espalhados pelo país. Mas, de acordo com o relato do jornalista, "era tal o sentimento de impunidade, que a melhor fonte acabou sendo mesmo o Diário Oficial"'.

De acordo com Kotscho (2006, p.12), após a publicação das reportagens, O Estado de $S$. Paulo sofreu pressão imediata dos militares e "Júlio de Mesquita Neto foi convocado pelo presidente Geisel para se explicar em Brasília". Antes disso, ao mostrar a série para o diretor de redação, Kotscho foi advertido sobre o que as reportagens poderiam causar.

Quando mostrei o trabalho a Fernando Pedreira, lembro-me bem, ele ficou mais assustado do que feliz. Pediu um tempo para ler tudo com calma, lembrou que o Congresso Nacional iria entrar em recesso, achou melhor só publicar a série em agosto e me recomendou férias. (KOSTCHO in MOLICA, 2005, 144)

Assim vivem os nossos superfuncionários ganhou o Prêmio Esso de melhor reportagem feita pela equipe do jornal, em 1976. Ricardo Kostcho dividiu o Esso com os colegas das sucursais e correspondentes que participaram do trabalho. A cerimônia de premiação naquele ano 
foi singela: contou apenas com a entrega do prêmio na redação, pela situação política do país e pelo tema da reportagem.

Com a série de reportagens escritas por Kotscho, pela primeira vez a palavra "mordomia" entrava para o vocabulário político. Isso, no entanto, não foi motivo para que as farras diminuíssem ou acabassem; elas continuam até hoje.

\begin{abstract}
Apesar do barulho provocado pelas matérias, a conseqüência prática das denúncias foi nula. Ninguém foi punido, ninguém perdeu seus privilégios, e as mordomias passaram a fazer parte do nosso vocabulário político, atravessando décadas, indo alegremente dos governos militares para os civis e sobrevivendo a qualquer tentativa de acabar com a impunidade dos donos do poder. (KOTSCHO, 2006, p. 13)
\end{abstract}

Depois da publicação de Assim vivem os nossos superfuncionários, a direção do jornal aconselhou Ricardo Kotscho a tirar férias. Além disso, alguns colegas do jornalista, que faziam cobertura da área militar, o aconselharam a se afastar por um tempo, pois, segundo eles, os militares “estavam de olho" no repórter. Esses conselhos contribuíram para que ele aceitasse o convite do Jornal do Brasil para ser correspondente na Alemanha.

É impossível negar a visibilidade que o jornalista ganhou depois do Prêmio Esso em 1976. Kotscho, que já trabalhava como jornalista há nove anos, depois do Esso passou pelos jornais Folha de S.Paulo, Jornal do Brasil e pela rede de televisão CNT. Antes de se tornar secretário de imprensa do presidente Luiz Inácio Lula da Silva, Kotscho atuou como assessor de imprensa de Lula em quatro campanhas à Presidência da República. Hoje, de volta à reportagem, é um dos diretores da revista Brasileiros.

Não fosse a boa memória dos jornalistas Getúlio Bittencourt e Haroldo Cerqueira Lima, provavelmente a reportagem Exclusivo: fala Figueiredo não estaria entre as vencedoras do Prêmio Esso de Jornalismo. Talvez nem tivesse passado da primeira lauda.

Ao entrarem na sala do general e futuro presidente João Figueiredo, em Brasília, naquele 4 de abril de 1978, os jornalistas imaginavam que poderiam usar o gravador e fazer anotações. Se enganaram. Ao perguntar a Figueiredo se poderiam fazer o registro, o sucessor de Geisel apenas fez um sinal de negativo com a cabeça.

Foi então que o jornalista mineiro Getúlio Bittencourt, na época com 26 anos, pôde colocar em prática a técnica que iniciara quando ainda era criança. A paixão por cinema fez com que Bittencourt, na infância, memorizasse as fichas técnicas de longas-metragens - os 120 filmes de John Ford, incluindo elenco, diretor de fotografia, música e tempo de duração. Na época, o futuro repórter também decorava todos os títulos originais dos filmes do sueco Ingmar Bergman. 
O treino de memória foi decisivo naquele momento. O que era para ser 20 minutos de conversa transformou-se em uma hora e trinta e cinco minutos de entrevista, com direito a palavrões e revelações do general que entraria para a história do país como um presidente que "dizia preferir cheiro dos cavalos ao cheiro do povo" (BELOCH e FAGUNDES, 2005, p. 82). O encontro chegou a ser interrompido mais de duas vezes pelo assessor de Figueiredo, mas ele ignorou os avisos e seguiu com a conversa.

De volta à redação, Bittencourt sugeriu a Cerqueira Lima que transcrevessem tudo o que havia sido dito na entrevista. Cerqueira Lima, no entanto, ficou surpreso e reticente; não tinha certeza se aquele formato daria certo. Já o secretário de redação do jornal Folha de S.Paulo, Alexandre Gambirásio, “teve um comentário desalentador ao ler as primeiras páginas: 'Onde é que está a notícia?'. Acho que ele mudou de idéia depois de ler o resto", relembra Bittencourt. (BITTENCOURT em entrevista à autora)

A conversa que os dois repórteres tiveram com Figueiredo rendeu, nos dois dias seguintes, duas matérias publicadas nos dias 5 e 6 de abril de 1978, no jornal Folha de S.Paulo.

A primeira reportagem teve entre 12 e 13 laudas. Bittencourt conta que, sob pressão, chegou a escrever 100 linhas por hora. Cerqueira Lima ficava responsável pela revisão das laudas. Por falta de tempo - pelo fechamento do jornal - e espaço, é que as reportagens foram divididas em duas partes. Bittencourt conta que, mais tarde, soube que Antonio Carlos Magalhães, na época um dos assessores de Figueiredo, tentou desmentir a matéria, que era a primeira a tratar diretamente do tema política, depois de anos de regime militar.

Um dos assessores do Figueiredo, Antônio Carlos Magalhães (...), me disse depois que propôs ao Figueiredo para desmentir tudo. O general não quis, porque achou que foi mesmo tudo gravado. ACM insistiu com ele: "Eu conheço um daqueles dois rapazes, o Getúlio. Outro dia ele falou comigo por 20 minutos, sem tomar notas nem gravar, e escreveu meia página na Folha de S. Paulo. Pode desmentir...” (BITTENCOURT em entrevista a autora)

Figueiredo nunca desmentiu o que foi escrito pelos jornalistas vencedores do Prêmio Esso de 1978. O presidente ficou irritado, e chegou a falar sobre isso em entrevistas posteriores a outros jornalistas. Uma delas foi no Jornal do Congresso Nacional, publicada por Sílvio Leite. (Apêndice II)

O Prêmio Esso de Jornalismo, sem dúvida, trouxe grande visibilidade aos jornalistas. No entanto, de acordo com depoimentos de Bittencourt, o prêmio não alterou o trabalho ou a rotina da dupla vencedora. Hoje, Getúlio Bittencourt segue na profissão, como editor-chefe do DCI (Diário Comércio, Indústria e Serviços). O outro autor da entrevista, Haroldo Cerqueira Lima, morreu em 1990. 
Já na Presidência, o general Figueiredo foi o responsável pela continuação do processo de abertura "lenta, gradual e segura". A abertura, entretanto, não foi suficiente para evitar assassinatos com motivações políticas, entre eles o do jornalista Alexandre von Baumgarten, em outubro de 1982.

Doze dias antes, o jornalista saíra com a mulher e um barqueiro para uma pescaria. O corpo do jornalista foi encontrado boiando, com três tiros, na praia da Macumba, no Rio de Janeiro.

Baumgarten era conhecido por ser um jornalista de direita - na época, ele era diretor da revista O Cruzeiro -, próximo dos serviços de informação do governo Figueiredo. Antes de morrer, o jornalista deixou um dossiê culpando chefes do SNI pela sua eventual morte e, principalmente, o general Newton Cruz (que seria inocentado por júri popular, em 1992). O documento foi parar nas mãos de quatro jornalistas, Francisco Vargas, Leda Beck, Norma Couri e Bella Stall, que na época trabalhavam na revista Veja.

Minha fonte disse que tinha o dossiê e combinamos de nos encontrar no saguão de um prédio comercial na Praça Mauá. Eu estava tenso, achava que todos ali em volta eram policiais. De repente, um senhor se aproximou e perguntou: 'Vargas?'. 'Sim', respondi. 'Isso é para você', e me entregou um envelope pardo. O sujeito sumiu de vista. Entrei no primeiro táxi que vi e, sem tirar totalmente os papéis do envelope, li as primeiras linhas do dossiê. Fiquei mais apavorado ainda, achei que o taxista era do Dops, que ia me matar. Quando chegamos ao destino, em Botafogo, onde ficava a sucursal da Veja, paguei a corrida e saí rápido do carro, mas o motorista ainda me falou, bem sério, me encarando: 'bom trabalho'. Entrei correndo no prédio, morrendo de medo, mas com um Prêmio Esso debaixo do braço. (Xico Vargas in BELOCH e FAGUNDES, 2006, p. 95)

Sob o medo de serem descobertos e assassinados, os jornalistas Norma Couri, Francisco Vargas, Bella Stall e Leda Beck trabalharam durante vários meses no Caso Baumgarten. (COURI em entrevista à autora)

Norma Couri conta que, como em um filme do agente James Bond, pessoas eram mortas com estocadas de guarda-chuvas que continham veneno na ponta. "Acontecia na rua, perto de uma banca de jornal; de repente o sujeito caía como se tivesse um ataque cardíaco", conta a jornalista. Por isso, o medo de ser alvo do governo era comum na época.

Os quatro repórteres envolvidos na apuração da reportagem costumavam trabalhar até de madrugada para concluir as reportagens. As matérias, publicadas na revista Veja, em 1983, e ganhadoras do Prêmio Esso no mesmo ano, exigiram muita pesquisa de campo, apuração e sigilo.

O cuidado em não revelar fontes se mantêm até hoje. Uma das repórteres vencedoras do Prêmio, Norma Couri não revela ou cita nomes quando se refere ao episódio, provavelmente por continuar na profissão, assim como os outros colegas da área, que fizeram parte do Caso Baumgarten. 
Além das lembranças do tempo de apuração, Norma Couri, que ainda trabalha como repórter de publicações brasileiras e estrangeiras, relembra a aflição de ter o carro arrombado e do medo constante na época. Apesar disso, a repórter acredita que o jornalismo feito durante aqueles anos de regime militar tendia, sim, a ser melhor que o jornalismo atual.

\begin{abstract}
O jornalismo investigativo durante o período militar era difícil, eu mesma tive meu carro arrombado e uma pasta com um dossiê de matéria que eu fazia sobre a morte suspeita de uma pessoa, roubado, apenas esta pasta, com fotos e provas. Foi um período de medo que durou muito tempo depois da anistia; ninguém acreditava que os 21 anos haviam acabado. (...) Tendo a achar que se fazia um jornalismo melhor, sim, com mais informação, com mais tempo para apurar casos como o do Baumgarten. Hoje quem coloca quatro jornalistas na apuração de um caso até o final, dure o que durar? (COURI em entrevista à autora)
\end{abstract}

Eram 18h de uma sexta-feira; fim de maio de 1969. Durante o fechamento do jornal $O$ Globo, que traria na primeira página uma possível abertura do governo, o editor político do jornal, Carlos Chagas, recebe um telefonema do ajudante de ordens do presidente Costa e Silva:

- Carlos Chagas, o presidente quer falar com você.

- À que horas?

- Venha aqui às $19 h$.

Imaginando que iria participar dos tradicionais encontros entre o presidente e jornalistas, Chagas seguiu para o Palácio das Laranjeiras para conversar com Costa e Silva. Antes de ir ao encontro, Chagas pedira ao secretário de redação para não fechar o caderno de política. O presidente, pensava o jornalista, poderia vir com alguma novidade.

Já no Palácio das Laranjeiras, no Rio de Janeiro, o editor de $O$ Globo assustou-se ao perceber que não havia nenhum outro jornalista à espera para o encontro. Ainda considerou ter errado o horário, mas o ajudante de ordens do então presidente confirmou:

- Pode entrar, o presidente está te esperando.

- Mas e os outros?

- Não tem outros, não. É só você.

De frente para Costa e Silva, o jornalista mal podia acreditar nas coisas que escutava: "eu não passo à História como ditador; eu não sou um general sul-americano que simplesmente golpeou as instituições. Eu vou acabar com o AI-5", afirmava o presidente. E continuou: 
Eu vou convocar uma comissão de juristas, pra fazer uma emenda à Constituição. Vou me reunir com eles, por um mês, ou o tempo que seja necessário. Vamos repassar a Constituição e, em seguida, eu vou reabrir o Congresso e mandar essa emenda para o Congresso. E no dia que eu mandar, vou revogar o AI-5. Está todo mundo usando o ato em meu nome, prendendo e fazendo o diabo. (CHAGAS em entrevista à autora)

As revelações dariam no mínimo três manchetes seguidas para a edição de sábado do jornal carioca. Mas antes que Chagas pudesse voltar à redação para publicar a notícia, Costa e Silva impede o editor de seguir com a idéia e explica que tudo aquilo era off the record, isto é, não poderia ser publicado. O presidente ainda explicou o interesse em conversar com Chagas e fez, então, um convite.

Eu estou tendo muita resistência pra fazer isso, resistência militar. E eu te chamei aqui porque eu te conheço, os políticos te conhecem, você é editor político do Globo e eu estou fazendo algumas mudanças no meu Gabinete. Quero que você venha ser o meu porta-voz, pra dar essas notícias lentamente, em pílulas, pra não assustar ninguém, para a gente chegar ao objetivo final. (CHAGAS em entrevista à autora)

Sem jamais ter imaginado uma mudança para Brasília, e muito menos "trabalhar com um ditador", como o próprio Chagas o descreve, o jornalista aceita o convite, pensando: "é um ditador que vai acabar com a ditadura".

Vivendo em Brasília e como porta-voz, Carlos Chagas participava, três vezes por semana, de reuniões com Costa e Silva e juristas. Eles discutiam, entre outras coisas, o fim do AI-5.

No fim de maio foi marcada a data de abertura do Congresso e fim do AI-5. Seria em 7 de setembro. Porém, antes que isso pudesse acontecer, Costa e Silva se viu impedido de levar adiante seus planos, em Brasília. Em viagem ao Rio de Janeiro, Carlos Chagas percebe que há algo estranho com o presidente. No vôo de Brasília para o Rio, Costa e Silva viajou o tempo inteiro deitado, usando cachecol. Apenas alguns militares sabiam do início do processo de derrame do general-presidente, entre eles o médico e capitão do exército Élcio Simões Gomes.

O processo da trombose, do derrame cerebral se acelerava, por conta da viagem. Aí, ele com gestos, pede ao ajudante de ordens, uma folha de papel. Pega a caneta - a mão direita estava boa -, e tenta assinar o nome, mas o comando do cérebro já não consegue chegar mais na ponta da caneta. Então não sai mais Artur da Costa e Silva, sai 'A Silva', 'Co Silva'... Ele tenta várias vezes, não consegue, a caneta cai no chão, e ele começa a chorar compulsivamente - esse é o depoimento do ajudante de ordens. Vinte minutos depois ele estava em estado de coma, já com o derrame cerebral consolidado. Aí chamam os juristas, chamam gente... Não dava mais para esconder. O próprio militar lá me diz: 'não é gripe, não. É um derrame'. (CHAGAS em entrevista à autora)

A partir daí, começa a contagem regressiva: foram 113 dias de angústia do presidente entre o impedimento de governar e a morte. Nesse período, já impossibilitado de continuar à frente da Presidência, Costa e Silva deveria ser substituído pelo vice-presidente, Pedro Aleixo. O vice, que era contra o AI-5, é impedido pelos militares de assumir o posto e levado preso, na casa da filha no Rio de 
Janeiro. No lugar dele, assume uma junta militar. A semana reservada para o fim do AI-5 deu lugar à usurpação do poder.

Com isso, o porta-voz da Presidência pede demissão, mas ainda assim permanece no cargo, à pedido do chefe da Casa Civil, caso o presidente tivesse uma melhora.

Em outubro, Chagas retorna para $O$ Globo. Com muitas das anotações feitas em um quarto de hotel, em Brasília, o jornalista dá início a série de 22 reportagens sobre a doença e morte do presidente Costa e Silva. A série, intitulada 113 dias de angústia - impedimento e morte de um presidente, foi publicada em 1970. Chagas levou quatro meses entre a apuração e redação do texto e, nesse período, recebeu documentos secretos de um coronel, colega dele, além de colher depoimentos de pessoas que também vivenciaram de perto o drama do então presidente.

Para dificultar a censura das reportagens, o jornalista sugeriu ao dono do jornal $O$ Globo, Roberto Marinho, que publicasse as matérias também em um jornal de grande porte, em São Paulo. Escolheram, então, $O$ Estado de S. Paulo.

Além disso, graças ao cargo de porta-voz que ocupou durante alguns meses, Carlos Chagas conseguiu burlar os censores, que diziam "esse jornalista foi o porta-voz, secretário de imprensa do Costa e Silva, então ele está conosco... Pode publicar".

Eu comecei a escrever contando a luta do Costa e Silva para abrir o país. Aí todo mundo gostou - os militares não reclamaram. Mas comecei também a contar detalhes que deixavam muito mal a junta militar. Mas as reportagens já estavam fazendo sucesso no Estadão e n'O Globo, todos os dias. Eles foram engolindo... Aí quando foi na penúltima e na última, que não tinham nada de mais até, era já o fím - a morte do Costa e Silva - aí eles me abordaram e disseram: 'tem que trazer para censurar'. Mas tudo o que eu tinha que falar, eu já tinha falado. Eles bobearam nessa história. (CHAGAS em entrevista à autora)

Com a repercussão das matérias, $O$ Globo passou a ser constantemente pressionado pelo regime militar. Assim, o jornal deu espaço a um coronel do Ministério do Exército, que desmentiu as informações de Chagas em outras quinze reportagens, segundo informações do próprio jornalista. As matérias do militar, no entanto, foram assinadas por um colega de Chagas. Segundo Carlos Chagas, Roberto Marinho nunca justificou ou mencionou essas quinze matérias.

O Prêmio Esso de Jornalismo, conta Chagas, foi parte muito importante na profissão. A imagem dele estava destruída, depois de ter sido "porta-voz da ditadura", como o jornalista define. A série de reportagens foi responsável por trazê-lo de volta ao jornalismo. Depois do Esso, Chagas mudou-se para Brasília, em 1972, e tornou-se diretor da sucursal de $O$ Estado de S. Paulo. Atuou também em outros órgãos de imprensa ao longo dos anos, além de ter sido professor de jornalismo na Universidade de Brasília (UnB) por muitos anos. Atualmente, Carlos Chagas tem uma coluna política reproduzida em diversos jornais brasileiros. 
O repórter Luiz Fernando Emediato era conhecido como "o esquisitão que tinha decidido escrever sobre a turma". Durante mais de três meses, em 1982, o jornalista de O Estado de S. Paulo, então com 31 anos, viveu literalmente como jovens usuários de drogas. Ele vestiu-se como os meninos e meninas, fumou maconha, acompanhou os conflitos, indecisões e desencontros de muitos deles. A intenção era mesmo se misturar aos personagens, com a certeza de que não perderia o distanciamento. Tornara-se um deles para descrever melhor aquele universo.

À pedido da direção do jornal, Luiz Fernando Emediato deu início a série de reportagens batizada de A Geração Abandonada. Para a reportagem, Emediato entrevistou mais de mil jovens em centros urbanos de todo o país. A pauta, porém, foi adaptada pelo repórter, que na época considerou a sugestão da direção "burocrática e conservadora". A idéia inicial da chefia era produzir uma matéria especial sobre o consumo de drogas pelos jovens de São Paulo.

Para dar credibilidade ao trabalho, voltado agora para o comportamento dos jovens e suas relações sociais, Emediato pesquisou arquivos do jornal, que descreviam a crise de gerações e o uso de drogas pelos meninos e meninas. No entanto, percebeu que as reportagens sobre esse assunto pouco enfocavam as causas e eram "pesquisas rasas de especialistas", segundo o repórter. Para fugir desse tipo de matéria foi que Emediato decidiu unir a observação à pesquisa.

Luiz Fernando Emediato passava o dia observando e convivendo com os jovens. Chegou a fazer amizades; duas delas se mantêm até hoje. Em nenhuma ocasião, porém, Emediato gravou as conversas dos personagens. Apenas "vivia o momento" e à noite anotava tudo em uma espécie de diário que manteve durante os meses de apuração. Ele também procurava não mencionar que era um jornalista, pensando que isso poderia prejudicar e inibir o comportamento dos jovens. Ao final da série de reportagens, Emediato revelou a alguns jovens a sua identidade.

O gosto pela literatura e a idéia de ser fiel aos personagens com quem tinha vivido durante quase três meses fez com que Emediato escrevesse a série na primeira pessoa, explorando o chamado Jornalismo Literário. O formato deu certo e a Agência Estado vendeu as reportagens para os principais jornais de 14 cidades: Manaus, Recife, Salvador, Fortaleza, Belém, Belo Horizonte, Curitiba, Goiânia, Cuiabá, Florianópolis, Porto Alegre, São Luís, Natal e São Paulo.

Simultaneamente a publicação da série, o jornal veiculou aquela que talvez tenha sido a mais completa pesquisa realizada até então para apontar o perfil do jovem brasileiro nas principais cidades do país. Mais de 1.300 jovens foram entrevistados e revelaram não confiar no governo e não gostar da sociedade em que viviam. Manifestaram o desejo de participar de decisões a cargo dos adultos, como forma de escapar do isolamento e da desinformação. E mostraram-se, finalmente, ao contrário do que afirmavam os sociólogos, conformistas e conservadores, apáticos e passivos. (BELOCH e FAGUNDES, 2006, p. 93) 
O ajuste inicial na pauta, feito por Emediato, e a maneira ousada com que descreveu o universo daqueles jovens, lhe renderam o Prêmio Esso em 1982. Depois disso, o jornalista recebeu seis convites de editoras para a publicação de um livro, que ele mesmo publicou pela editora que abriu, a $E M W$ Editores. Com o fim da EMW, em 1992, Luiz Fernando Emediato criou a Geração Editorial. Hoje Luiz Fernando Emediato é presidente do Codefat (Conselho Deliberativo do Fundo de Amparo ao Trabalhador). A redação Emediato abandonou depois de 17 anos de carreira.

Eu na verdade jamais gostei de jornalismo do jeito que ele é. Para mim é uma tortura trabalhar em jornal e cobrir o dia-a-dia, ou editar o dia-a-dia (fui chefe de reportagem, editor, diretor de redação, diretor de jornalismo). O que eu gostava era de grandes séries, de misturar jornalismo e literatura. Isso foi desaparecendo dos jornais. Eu não sei se conseguiria trabalhar num jornal como os de hoje. Então, de repente, num dia, eu disse para mim mesmo: chega de jornalismo. (EMEDIATO em entrevista à autora)

Quando recebeu o documento com a estampa "confidencial", em 1980, Jorge Oliveira, então chefe de reportagem do Jornal de Brasília, decidiu que iria, de uma maneira ou de outra, transformar aquelas informações em uma matéria. O documento, datado de fevereiro de 1980, trazia nomes de opositores do acordo nuclear firmado entre Brasil e Alemanha em 1975. A lista incluía judeus, comunistas, empresários, parlamentares, cientistas, além de jornais impressos.

Cinco anos antes da publicação da reportagem, para tentar garantir a autonomia nacional em termos de recursos energéticos e também manter os resultados do "milagre brasileiro" foi que o presidente Ernesto Geisel assinou o tratado para implantação do programa nuclear.

De volta à década de 80 , durante uma reunião de editores do jornal Oliveira arriscou falar sobre o documento, que havia recebido de uma fonte, com Francisco Baker, editor-chefe do jornal:

- Baker, eu tenho um documento aqui interessantíssimo para a gente publicar.

- É mesmo?

- É. É um negócio que vai estourar aí, é um grande material que pode dar um problema seriíssimo.

Eu me arrependo até hoje de ter dito que era um grande documento e que ia dar um problema sério, porque ele começou a ficar nervoso. Ele perguntou se o documento estava comigo e eu respondi 'o documento está comigo, mas eu não vou mostrar. Só mostro se você achar que deve publicar'. Ele perguntou: 'sobre o quê é?”. E eu: ‘é um documento sobre energia nuclear, e está entregando judeu, americano'. E ele: 'rapaz, não vamos tocar nesse assunto'. Era um absurdo; existia uma censura dentro do jornal. Âs vezes nem era o jornal em si, mas os caras que estavam administrando o jornal, por uma questão de preservação dos cargos ou de se preservarem, tinham medo de publicar e colocar essas coisas, e de serem demitidos e substituídos, que era a coisa mais fácil que existia. (OLIVEIRA em entrevista à autora) 
Provavelmente por receio, Baker sugeriu que eles primeiro publicassem uma notinha no Decálogo - coluna política do Jornal de Brasília, tratando da existência de um documento da Divisão de Segurança e Informação, que o Serviço Nacional de Informação havia mandado. Jorge Oliveira, porém, não gostou da idéia. "Ele vai desmanchar o meu documento e se reclamarem, eu não vou publicar nada. Eu senti que não ia dar em nada“, pensou o jornalista.

Por isso, naquela véspera de feriado de Corpus Christi de 1980, Jorge Oliveira se aproveitou do fato de estar de plantão para publicar a matéria. Ele primeiro conversou com o diagramador do jornal. A idéia era colocar o assunto na primeira página do veículo. Oliveira iria ainda mais longe: em vez de uma linha, ele pediu para que o colega responsável pelo layout colocasse três linhas como manchete. De acordo com o jornalista, naquela época, o Jornal de Brasília seguia os moldes do Jornal do Brasil, ou seja, utilizava apenas uma linha na primeira página do jornal.

Quando a matéria saiu, numa quinta-feira, 05 de junho de 1980, o primeiro telefonema que Oliveira recebeu foi o de Francisco Baker.

- Você está demitido. Os donos do jornal estão putos contigo. Você está demitido e não apareça aqui. Isso é uma covardia, o que você fez, porque eu tinha dito que a gente ia colocar no Decálogo primeiro.

- Baker, a merda está feita; não tem mais para onde correr. A notícia é muito mais importante do que o dono desse jornal - um goiano filho da puta. - Eu esculhambei. E fiquei em casa.

Depois de 24 horas de demissão, Oliveira foi chamado para fazer parte da equipe do Jornal de Brasília novamente. Isso porque outros veículos, como Folha de S.Paulo, O Globo, O Estado de S. Paulo e o Jornal do Brasil reproduziram o dossiê.

Eles não podiam dizer que tinham demitido o repórter que havia feito aquela matéria. Aí eles me chamaram de volta. 24 horas depois eles me readmitiram, mas por quê? Porque os jornais deram cobertura e viram a importância do documento. Eu cheguei no jornal como 'o grande furão - o maior furão de todos os tempos'. (OLIVEIRA em entrevista à autora)

Àquela altura, todos se perguntavam quem havia fornecido o documento confidencial ao repórter. Para despistar, já que não tinha a intenção de revelar a fonte, dias antes da publicação Oliveira pediu a um colega, que era deputado, para assumir a responsabilidade. O peemedebista José Costa aceitou a missão. Um dia depois de publicada a reportagem, Costa foi à redação para ser fotografado segurando o jornal que estampava a reportagem "Relatório aponta opositores do acordo nuclear". O 
repórter conseguiu o que queria: preservou por mais de vinte anos a fonte que entregara o dossiê a ele - o assessor-chefe da Eletrobrás Carlos Alberto Castelo Branco, já falecido.

Apesar do processo de abertura política no país, a divulgação do relatório contendo os nomes dos opositores do programa nuclear acirrou a relação entre os militares e os veículos de comunicação, principalmente jornais impressos. Com a publicação, o Jornal de Brasília recebeu diversas ameaças de bombas. Os telefonemas anônimos também se tornaram freqüentes. Além disso, o repórter teve o canuíte do freio do carro cortado, quando estava no Rio de Janeiro, meses depois da publicação da matéria. Ele bateu o carro na avenida Wenceslau Brás, mas conseguiu sair sem ferimentos. "Isso não me abalou em absolutamente nada", conta. Oliveira lembra que no período da censura escrevia mesmo quando sabia que um assunto não iria sair. "Mesmo que o censor falasse que não poderia escrever sobre aquele assunto, eu escrevia. Nem que fosse para ele jogar na cesta do lixo", afirmou.

Depois da reportagem que lhe renderia o Prêmio Esso em 1980, Jorge Oliveira permaneceu no Jornal de Brasília cerca de um mês. De lá, seguiu para ser repórter do Jornal do Brasil.

Foi no Jornal do Brasil que Jorge Oliveira recebeu o Prêmio Esso pela reportagem que fez enquanto era chefe de reportagem do Jornal de Brasília. A premiação não contou com comemorações; a redação funcionava normalmente naquele dia. Apesar da vida do repórter não ter mudado com a premiação, o Esso pode ser considerado, segundo Jorge Oliveira, o "coroamento da profissão".

Depois de passar pelo $J B$, o vencedor do Esso foi também diretor de jornalismo da Rádio Nacional. Em 1987, Jorge Oliveira abandonou as redações e abriu o próprio negócio. Segundo ele, o jornalismo ficou "burocratizado" demais. O jornalista começou, então, a trabalhar com marketing político. Ele foi o responsável, por exemplo, pela $1^{\text {a }}$ campanha presidencial de Leonel Brizola, em 1989. Na década de 90, Jorge Oliveira montou uma produtora e desde então dirige documentários.

Em sete cadernos especiais do Jornal da Tarde, publicados entre 17 a 24 de junho de 1971, estavam descritos os maiores problemas da maior cidade do Brasil. São Paulo tinha quase seis milhões de habitantes no início da década de 70, sendo que três milhões viviam sem água encanada. O número de crianças carentes na cidade também era alto - 600 mil.

Quando o prefeito-nomeado José Carlos de Figueiredo Ferraz estava para iniciar o mandato, o então diretor do Jornal da Tarde, Ruy Mesquita, recebeu a seguinte proposta: a de realizar um seminário com técnicos, para abordar os problemas vividos por São Paulo.

A missão de converter os 15 encontros em matérias especiais para o jornal ficou a cargo dos repórteres José Maria Mayrink e Ricardo Gontijo. Durante 40 dias, ambos participaram de reuniões com especialistas. No fim, eles tinham as discussões documentadas, que somavam 15 horas de gravação e mais de 30 horas de taquigrafia. 
O desafio era transformar todos aqueles relatórios burocráticos, repletos de estatísticas, em algo que se aproximasse da realidade da população. A partir das discussões, que serviam como roteiros, os repórteres foram às ruas para entender melhor o que havia sido documentado por mais de 70 técnicos. Mayrink e Gontijo também compararam dados oficiais àqueles do Seminário de Problemas Municipais. As reuniões, que eram realizadas no salão do Arquivo-Biblioteca do jornal O Estado de S. Paulo, abordavam dez temas: serviços públicos, uso do solo, circulação e transporte, abastecimento municipal, saúde pública, habitação, bem-estar social, educação e cultura.

Devido a grande quantidade de informações, as reportagens foram divididas - diariamente eram publicadas quatro páginas sobre os problemas de São Paulo. Além do levantamento das principais dificuldades enfrentadas pela cidade, houve a preocupação de apontar possíveis soluções a curto, médio e longo prazos. Segundo Mayrink, as reportagens nunca sofreram qualquer tipo de censura, nem antes e nem depois da publicação.

Por insistência e iniciativa de Gontijo, a série foi inscrita no Prêmio Esso. Receita para São Paulo ganhou o prêmio em 1971. Segundo Mayrink, o Esso sempre foi motivo de orgulho para ele que, quando ganhou, tinha cinco anos de profissão.

O Prêmio Esso, mais do que outros prêmios naquela época e ao longo de muitos anos, era uma consagração para qualquer repórter. Eu tinha, em 1971, cinco anos de profissão e estava começando minha experiência em São Paulo, após ter passado um ano em Belo Horizonte (Correio de Minas e Diário de Minas) e 4 anos no Rio (JB). A premiação me trouxe certo prestígio, respeito dos colegas e satisfação pessoal. Como escrevi em Vida de Repórter, eu não acreditava que fosse ganhar o prêmio. (MAYRINK em entrevista à autora)

Embora tenha aderido ao plano de demissão voluntária, em 2006, José Maria Mayrink foi contratado por $O$ Estado de S. Paulo como pessoa jurídica. Depois de 45 anos de profissão, ele ainda atua como repórter, produzindo matérias, viajando quando necessário e participando de plantões.

Corrupção em jogos de futebol não era um tema recorrente na mídia da década de 60. Desde 1961, porém, o assunto era pesquisado pelo jornalista Vital Battaglia, quando ele ainda fazia parte da equipe do jornal Última Hora. Depois de alguns anos de análise, um dado chamou a atenção do repórter. Ele percebeu que em cidades onde o presidente da Federação Paulista de Futebol, deputado João Mendonça Falcão, tinha votação expressiva, os clubes conseguiam bons resultados em campo.

Alguns anos depois, já em $O$ Estado de $S$. Paulo, o repórter passou a acompanhar e a estudar, juntamente com o colega Hedyl Valle Jr, os resultados políticos e os de futebol, de várias cidades de São Paulo. Foram quase seis meses de apuração. Acompanhando o assunto mais de perto, depois de diversas conversas com as fontes - entre elas, jogadores, filhos, esposas e amigos - os dois jornalistas conseguiram, em 1967, denunciar um esquema de favorecimento de clubes em troca de dinheiro. "Chegamos a passar 72 horas seguidas nos revezando defronte a casa da pessoa que considerávamos o 
chefe do "esquema'", relembra Battaglia. Segundo ele, com o início da série, publicada entre setembro de 1967 e janeiro de 1968, muitas pessoas criaram coragem para procurar os repórteres, com o intuito de denunciar esquemas de corrupção no futebol. Além de juízes que atuavam em São Paulo, as reportagens denunciaram profissionais do Rio de Janeiro, que estavam a serviço da antiga CBD (Confederação Brasileira dos Desportos). Escândalos de arbitragem em Copas do Mundo também entraram na série de $O$ Estado de S. Paulo. Mas, de acordo com Vital Battaglia, muitos dirigentes não acreditavam que a reportagem pudesse sair no jornal sem que os jornalistas apresentassem provas concretas.

\footnotetext{
Naquele tempo as pessoas sabiam que bastaria um simples desmentido para saírem fora do processo e desacreditar o repórter. Muitos dirigentes do interior chegavam a se vangloriar de "comprar" árbitros em favor do clube de sua cidade. Jamais imaginavam que um jornal tivesse a coragem de publicar reportagens sem provas contundentes. (BATTAGLIA em entrevista à autora)
}

Antes da publicação, algumas pessoas tentaram impedir, sem sucesso, que as informações viessem a público. Segundo Battaglia, uma delas era o dono de uma emissora de rádio e televisão, de uma grande indústria de cimento. Apesar disso, a série de reportagens batizada de Juiz, ladrão e herói não sofreu censura. Depois da divulgação, porém, Vital Battaglia e Hedyl Valle Jr passaram a ser ameaçados.

O Hedyll disse-me certa vez que estava sendo seguido na saída do jornal. Mas como geralmente saíamos em grupo, nada de grave aconteceu. No meu caso recebi telefonemas, ameaças de que seria morto se voltasse a determinada cidade. E o presidente da FPF (Federação Paulista de Futebol) disse-me que eu iria para a cadeia e encerraria minha carreira. Chegou a me oferecer uma cadeira como Juiz do Tribunal de Justiça Desportiva. (BATTAGLIA em entrevista à autora)

Além das ameaças, os juízes entraram com processo contra o jornal e também contra Battaglia, que respondeu a 34 processos. O repórter perdeu em apenas um caso. O Estado de S. Paulo publicou ainda uma carta aberta ao presidente da Federação Paulista de Futebol, reiterando a existência das provas conseguidas pelos repórteres.

Juiz, ladrão e herói foi vencedora do Prêmio Esso em 1968. Depois deste primeiro prêmio, Vital Battaglia voltou a ganhar o Esso por mais 10 vezes, em diferentes categorias. Após passar pelo Estado de S. Paulo, Vital Battaglia virou escritor e criador de sites. Ele dirige também uma editora e agência de publicidade. Segundo Battaglia, Hedyll Valle Jr morreu ainda jovem.

Ele era ao mesmo tempo testemunha e repórter. No dia em que recebeu a ligação que serviria de ponta-pé para a reportagem, Luiz Cláudio Cunha estava na redação da sucursal da revista Veja, em Porto Alegre, sem ter o que fazer. O telefonema anônimo, que recebera em novembro de 1978, 
informava sobre uma família uruguaia mantida presa em um pequeno apartamento da rua Botafogo. Por estar meio à toa naquela tarde de sexta-feira, o repórter resolveu conferir pessoalmente se havia uruguaios presos naquele bairro da capital gaúcha.

Com o clima propício para a investigação, graças à abertura política brasileira, Cunha, chefe da sucursal, seguiu para o local onde estavam as vítimas, junto com o fotógrafo João Batista Scalco. O fotógrafo, que já havia trabalhado na revista Placar, seria fundamental para identificar mais tarde um dos responsáveis pelo seqüestro, o ex-jogador de futebol e policial do DOPS (Departamento de Ordem Política e Social) do Rio Grande do Sul Didi Pedalada. Horas depois, já no apartamento, Cunha e Scalco foram recebidos pela exilada Lílian Celiberti - apenas pela fresta da porta, ela ainda tentou avisar que havia mais gente ali. Cunha se comunicou, então, com Lílian, em espanhol. Os policiais que estavam escondidos no apartamento pensaram que ele era Hugo Cortes (presidente do PVP, partido de esquerda do qual Lílian também era filiada). “A repressão uruguaia queria muito o Hugo porque ele era o líder da maior organização de esquerda de oposição ao regime militar. E sabiam que ele estava em Porto Alegre, onde descobriram a conexão dele (à Lílian)", conta Cunha.

Logo em seguida, sob a mira de dois revólveres, os repórteres foram forçados por policiais a entrarem no apartamento onde estavam Lílian Celiberti, Universindo Díaz e os dois filhos de Lílian, Camilo e Francesca. No entanto, o susto veio quando os policiais brasileiros perceberam que Luiz Cláudio Cunha falava português.

- Quem são vocês?, perguntaram os policiais

- Nós somos jornalistas da revista Veja, respondeu Cunha.

Senti que eles entraram na defensiva e ficaram desnorteados. Nesse momento deu para perceber que as coisas deram errado para eles: não poderiam matar a Lílian, não dava para matar mais o Universindo e as crianças que estavam presos no Uruguai e não dava para matar dois jornalistas brasileiros. Ia dar uma merda geral. Se fosse uma operação exclusivamente uruguaia talvez fizessem, mas como tinha brasileiro complicou. (CUNHA em entrevista à autora)

Scalco e Cunha permaneceram cerca de 20 minutos no apartamento. Quando perguntaram o que estava acontecendo ali, os policiais apenas disseram que estavam prendendo estrangeiros ilegais no país, coisa comum naquela época. Após esse episódio, os jornalistas foram liberados do cativeiro. Àquela altura, Luiz Cláudio Cunha ainda não tinha noção de que, na realidade, aquele episódio estava ligado à Operação Condor, serviço de repressão política das ditaduras do Cone Sul.

Assim que descobriram do que se tratava, Cunha e Scalco deram início à investigação. Eles passaram, então, a fazer campana na frente do prédio. Segundo Cunha, muitas vezes eles amanheciam na frente do prédio "comendo frango assado ou sanduíche para tentar ver um cara saindo do 
apartamento, para poder dizer se aquele era o cara que estava no apartamento". A investigação dos jornalistas durou cerca de um mês.

Segundo Cunha, "a polícia passou a cumprir a função do jornalista a escrever notas e o jornalista passou a cumprir a função da polícia, que era investigar. Essa inversão de valores mostra como estávamos perdidos".

Alguns dias depois da primeira reportagem da revista Veja sobre o seqüestro, Lílian e Universindo reapareceram em uma prisão, em Montevidéu, enquanto os filhos da uruguaia tinham sido entregues aos avós.

Além das ameaças à revista, Cunha tinha que depor a todas as CPIs de investigações, a uma comissão da polícia, a uma CPI da Assembléia, a uma investigação da Polícia Federal, a quatro investigações paralelas e a uma outra da secretaria de segurança. Mesmo sob o regime militar, que ainda se fazia presente naquele fim da década de 70, e ainda com as ameaças à Veja, segundo Cunha, a revista não enfrentou dificuldades em publicar a reportagem sobre o seqüestro dos uruguaios.

Quanto à apuração, conta o jornalista, uma das dificuldades era a possível "mistura" entre o repórter e o personagem, já que ele havia presenciado, no cativeiro, o que estava acontecendo naquele momento. O difícil, segundo ele, era manter o distanciamento necessário para relatar a situação sem usar o "eu" o tempo inteiro. Para ajudar no processo, o editor Jorge Escosteguy pautava e editava, dando um tom mais neutro ao material.

Era um sentimento de frustração. Às vezes você não pode se movimentar como um repórter normal, porque o fato de você ser personagem da notícia atrapalha. Então eu acho, para o repórter, ruim isso. O repórter deve ser sempre testemunha da história, para contar a história para os outros. Quando ele é a própria peça do evento, ele acaba ficando um pouco travado nisso aí. Isso me atrapalhava um pouco. (CUNHA em entrevista à autora)

A colaboração da imprensa também foi fundamental no processo de investigação.

Esse é um trabalho coletivo de imprensa, não só de uma pessoa. Eu apareço apenas como uma testemunha, mas na verdade teve toda a sucursal trabalhando, teve o Zero Hora, as sucursais da grande mídia - Folha, Globo, Jornal do Brasil - fazendo uma cobertura sistemática: quando um não conseguia avançar, outro vinha e dava "uma porrada" neles. Então, é um mutirão que não tem uma coordenação, mas ele acontece naturalmente. A ditadura unia todos nós, na luta para tentar investigar essa coisa. Esse processo acaba sendo didático, no sentido que mostra que mesmo em um processo fechado, você consegue avançar, consegue investigar, quando você tem vontade política para isso. (CUNHA em entrevista à autora)

Lílian Celiberti, Universindo Díaz e os dois filhos de Lílian, Camilo e Francesca, fizeram parte das estatísticas: eles estavam entre os 180 uruguaios, vítimas de seqüestros no exterior, porém com um final diferente dos outros. Passados cinco anos, com a redemocratização do Uruguai, os exilados foram 
soltos. Além disso, o governo gaúcho indenizou a família e depois, já na democracia, o governo uruguaio também indenizou as vítimas do seqüestro.

Com as reportagens intituladas de $O$ Seqüestro dos Uruguaios, Luiz Cláudio Cunha e João Batista Scalco ganharam o Prêmio Esso em 1979. A notícia do Esso chegou por meio do também jornalista e escritor Zuenir Ventura, que ligou do Rio de Janeiro para avisar ao colega.

\begin{abstract}
A própria matéria, que durou cerca de um ano, já tinha me dado visibilidade. Eu era o repórter, mas também uma testemunha. O reconhecimento é algo claro, mas não acho que tive promoções, ganhei ou perdi emprego por casa do Esso. Se fosse assim, seria injusto. A gente todo dia está matando um leão. Tem de estar mostrando para o chefe que valeu investir naquela pauta. Acho uma bobagem ficar dependurado nesse negócio de prêmio. Mas foi um puta reconhecimento e tive muito orgulho. Sei que, quando converso com a Lílian e o Universindo, sei que eles estão vivos devido ao trabalho da imprensa brasileira. (...) Não foi o trabalho de uma pessoa só. Teve o trabalho de toda uma sucursal, de vários jornais. Naquele momento todos nós éramos aliados, os patrões, que tinham o negócio prejudicado com a censura, e os jornalistas de todas as redações, todos contra a ditadura. (CUNHA em entrevista à autora)
\end{abstract}

Depois da revista Veja, Luiz Cláudio Cunha foi chefe da sucursal de Brasília do Estado de S. Paulo, foi também repórter da sucursal de Brasília em $O$ Globo, passou pelo Correio Braziliense (repórter e colunista) e trabalhou na revista Istoé, como repórter especial. Além disso, fez campanhas políticas. Ele também trabalhou em agências de publicidade. Atualmente, Cunha é consultor de comunicação.

Sem qualquer fonte policial, os jornalistas Amicucci Gallo e Valério Meinel colaboraram no desfecho de um dos casos mais emblemáticos da década de 70: o da morte da jovem de classe média Cláudia Lessin Rodrigues, no Rio de Janeiro. Ela tinha 21 anos quando foi assassinada, em julho de 1977, por dois homens - George Khour e Michel Frank. Este último era filho de um milionário empresário carioca.

Em 1977, Amicucci Galo era repórter fotográfico freelancer da revista Veja. Na época, ele fora escalado pelo então editor, Zuenir Ventura, para fazer uma reportagem sobre o Esquadrão da Morte na Baixada Fluminense. Quando trabalhava neste caso, Gallo recebeu uma ligação informando sobre o corpo da jovem, que havia sido jogado nos penhascos da Avenida Niemayer. Entretanto, segundo Gallo (2007, 261), “a Veja preferiu se abster num primeiro momento". Depois de um mês de publicação de cobertura da mídia sobre a morte de Cláudia, e sem a participação oficial da revista no caso, os dois repórteres, por conta própria, decidiram iniciar as investigações jornalísticas.

A intenção de ambos era provar que o milionário Michel Frank era culpado pela morte de Cláudia Lessin Rodrigues. Àquela altura, a linha de investigação da polícia tinha mudado, e era nítida a manobra para que o processo fosse arquivado - o detetive à frente do caso fora afastado depois de produzir, de maneira eficiente, as primeiras conclusões e conceder declarações à imprensa. 
Segundo Gallo, uma das fontes passou uma informação imprescindível: a de que o médico patologista Domingos de Paola seria a peça-chave do episódio. Ele tinha informações importantes. Entre elas a de que a família de Frank tentava livrar o rapaz das acusações, dizendo que a jovem morrera por ingestão de álcool e drogas. Com essa versão, tanto Michel Frank quanto o outro acusado, George Khour, responderiam apenas pelo crime de ocultação de cadáver. De Paola havia sido contratado pelo advogado de defesa de Michel, Evaristo Moraes Filho, para contestar o laudo do Instituto Médico Legal, mas desistiu do acordo a tempo.

Gallo e Meinel iniciaram a procura pelo médico patologista. Primeiro percorreram, sem sucesso, todos os hospitais públicos onde ele poderia trabalhar. Com dificuldade, os repórteres conseguiram, com um colega de profissão de De Paola, o telefone e o endereço dele. Passaram, então, a fazer plantão em frente à residência do especialista.

Além dos plantões em frente ao apartamento do médico em Copacabana, os jornalistas da Veja descobriram também o bar que De Paola freqüentava. Certo dia, porém, em uma das esperas em frente à casa dele, De Paola chegou de carro, mas se negou a conceder entrevista. Ainda assim, Meinel publicou uma nota na revista sobre a recusa dele. No entanto, após a nota, o médico Domingos de Paola resolveu falar.

Certa noite, ele deu de cara comigo e com Valério e disse meio bravo: "Vocês deram aquela nota. Pois agora eu vou falar". Não acreditamos. Para que nada atrapalhasse a entrevista ao Valério, eu pedi uma garrafa de uísque para os amigos dele. Naquela mesa de bar, ele contou tudo. Disse que havia sido contratado pelo Evaristo e que estivera com Michel - que negara o crime. Mas o médico viu sua mão machucada e desconfiou. Ao tomar conhecimento do laudo cadavérico, Evaristo constatou que a versão apresentada por Michel para a morte de Cláudia overdose por ingestão de drogas - era insustentável. Ela fora estrangulada e sofrera uma hemorragia provocada por pancadas no rosto. De Paola e Evaristo decidiram abandonar o caso. Respeitados em suas áreas de atuação, jamais aceitaram dizer algo que não fosse a verdade. De Paola não contestou o laudo e Evaristo não tentaria mais provar a inocência de seu cliente. A garrafa de uísque acabou e a entrevista também. (MOLICA, 2007, p. 262)

No dia seguinte, Gallo e Meinel escreveram, com a autorização do sub-editor Cláudio Bojunga, a reportagem que seria vencedora do Prêmio Esso de 1977. Os dois pretendiam entrevistar Michel Frank, que havia se mudado para a Suíça. Lá, Frank acabou envolvido com o tráfico de drogas e foi assassinado. Já George Khour foi preso, julgado e condenado. Ele cumpriu parte da pena a que foi condenado.

A reportagem $\mathrm{O}$ assassínio de Cláudia Lessin Rodrigues foi a primeira matéria policial a conquistar o Prêmio Esso de Jornalismo e também a ganhar a capa da revista Veja, em setembro de 1977. 
Atualmente, Amucucci Gallo é conselheiro da Associação Brasileira da Imprensa. Antes disso, ele passou pelos jornais $O$ Globo e Correio da Manhã e as revistas Exame, Manchete e Quatro Rodas. O repórter Valério Meinel morreu em 1997.

Em 30 de abril de 1981, cerca de 20 mil pessoas se reuniram para assistir no Riocentro, na Barra da Tijuca (RJ), ao show de comemoração ao Dia do Trabalho, organizado por sindicalistas e grupos de esquerda. Naquela noite, do lado de fora do local, uma bomba explodiu em um carro estacionado entre outros veículos. O suposto acidente matou o sargento do Exército Guilherme Pereira do Rosário e feriu o capitão Wilson Luís Chaves Machado. Os dois tinham ligação com o DOI-Codi.

No dia seguinte ao atentado, assim como o restante da imprensa, a equipe do Jornal do Brasil iniciou a apuração do episódio. As hipóteses eram muitas. Uma delas, a defendida pelo Inquérito Policial Militar, era de que os dois militares eram "vítimas inocentes 'de uma armadilha ardilosamente colocada dentro do carro do capitão"” (BELOCH e FAGUNDES, 2006, p. 89).

No entanto, durante o plantão de fim de semana, o repórter do $J B$ Fritz Utzeri recebeu uma ligação do colega Sérgio Fleury, que passou acidentalmente pela frente da 19ª Delegacia de Policial, na Barra da Tijuca. Na DP, observando atentamente, Fleury notou um Puma semidestruído, mesmo modelo daquele veículo envolvido no caso da noite anterior.

Tanto Fritz Utzeri quanto o fotógrafo de plantão partiram imediatamente para o local onde estava o veículo. No depósito, que continha carros acidentados e roubados, foram tiradas fotografias daquele Puma e Utzeri gastou aproximadamente duas horas analisando o automóvel. Depois de reveladas, as fotos foram mostradas ao capitão Sérgio Macaco, que entendia de explosivos.

\footnotetext{
"Isto é coisa de quem está começando a lidar com explosivos ou já lida há tanto tempo que pode acabar se descuidando", disse Sérgio na ocasião. No dia seguinte, o $J B$ publicou um croqui na primeira página, além de uma série de fotos do Puma explodido do capitão Wilson Machado, uma verdadeira perícia fotográfica, informando que a bomba explodira no colo do sargento, uma afirmação que o Exército procuraria negar, sem sucesso, durante todo o Inquérito Policial (um IPM fajuto, que acabou sendo desautorizado 15 anos depois pelos próprios militares, quando - já na TV Globo - reabri o caso num Globo Repórter, junto ao jornalista Caco Barcellos). Os militares atribuíram o atentado à ação de grupos clandestinos como a Vanguarda Popular Revolucionária, do capitão Lamarca, que já havia sido desbaratada na ocasião do episódio. (MOLICA, 2005, 274)
}

O Inquérito Policial Militar, entre outros fatores, apresentava a versão de que a bomba tinha sido encontrada pelos militares dentro do carro - ela estaria encaixada entre a porta do Puma e o banco da carona. A partir de uma reconstituição do Exército - que mostrava um "simulacro fiel do artefato, colocado dentro de uma bolsa (...) contendo em seu interior um pedaço cortado de uma lata de óleo Havoline (...) simulando um mecanismo detonador com relógio" (MOLICCA, 2005, 275) - os 
repórteres compraram uma bolsa semelhante e conseguiram também uma lata vazia de óleo, para fazer a medição. Eles foram, então, até um concessionário Puma para esclarecer a dúvida.

Coincidentemente, o proprietário do Jornal do Brasil tinha um Puma e era freguês de uma oficina próxima ao jornal. Nesta oficina, Fritz Utzeri e um outro colega tentaram colocar a bolsa com a bomba dentro do carro, mas, segundo o repórter, foi impossível. Desse modo, ficou comprovado, por meio da apuração e de fotos, que o Inquérito Policial Militar era mesmo "fajuto", como havia dito Utzeri.

A ampla cobertura da mídia e o abafamento do caso pelas autoridades provocaram uma crise no governo do general João Batista de Figueiredo. O chefe do Gabinete Civil, general Golbery do Couto e Silva, foi demitido porque defendia a total investigação do episódio.

Durante a apuração, segundo informações de Fritz Utzeri, um Passat branco com quatro homens em seu interior passou a perseguir o grupo do Jornal do Brasil. Quando estavam na oficina fazendo a medição da bolsa com a bomba dentro do carro, um colega de Utzeri contou que "um dos ocupantes do Passat lhe apontara uma metralhadora" (MOLICA, 2005, 276).

Batizada de Bombas no Riocentro, a reportagem do Jornal do Brasil foi vencedora do Prêmio principal do Esso em 1981. No mesmo ano, O Estado de S. Paulo ganhou o de melhor reportagem, com a matéria intitulada Riocentro.

Fritz Utzeri trabalhou em diversos veículos e empresas, entre eles, O Pasquim, O Globo e Fundação Roberto Marinho.

\subsection{ANÁLISE DAS REPORTAGENS}

Levando-se em conta as entrevistas realizadas neste trabalho, é possível destacar alguns fatores relevantes para a pesquisa. O primeiro deles, e talvez um dos mais importantes, está relacionado à contribuição das reportagens vencedoras do Prêmio Esso de Jornalismo à sociedade. Ao serem publicadas, elas ajudaram a revelar um país que era desconhecido por grande parte dos brasileiros e, de certa maneira, ampliaram o espaço de liberdade de expressão na imprensa mesmo quando o país vivia uma época marcada pelo autoritarismo.

O segundo está relacionado ao tipo de apuração feita. Em parte dos casos estudados, as informações foram conseguidas off the record, ou seja, as fontes não poderiam ser reveladas. Muitas vezes as fontes eram omitidas pelo medo e ameaça constantes dos militares. Em relação aos bastidores do Caso Baumgarten, por exemplo, a jornalista entrevistada, Norma Couri, em momento algum se mostrou disposta a revelar quais eram as fontes do caso, em depoimento escrito para esta pesquisa. "Fonte nunca deve ser revelada, em caso algum", disse em certo momento a jornalista. O vencedor do 
Esso em 1980, Jorge Oliveira, também resguardou a fonte por mais de vinte anos. Ele apenas revelou recentemente, para este trabalho, porque a fonte morreu há alguns anos.

Apesar das reportagens do Prêmio Esso terem sido publicadas em veículos com sede no eixo Rio-São Paulo, parte das premiadas buscaram suas histórias fora dessas cidades. Assim, as vencedoras contribuíram para que fatos relevantes de outras regiões do país fossem analisados, entre elas Expedição de Contactação dos Índios Kranhacarore, de José Marqueiz; e Exclusivo: fala Figueiredo, de Getúlio Bittencourt e Haroldo Cerqueira Lima.

Já as sugestões de pauta vieram, na maior parte dos casos, da chefia dos veículos de comunicação. Mesmo assim, os repórteres tiveram liberdade suficiente, tanto em relação à apuração quanto ao texto final, para escrever aquilo que consideravam essencial e de interesse público.

Em relação ao tempo de pesquisa das matérias, pode-se afirmar que elas levaram, em média, de três a quatro meses entre a apuração e publicação. Isso demonstra que, diferentemente da dinâmica dos jornais atuais, o jornalista das décadas de 60, 70 e 80 podia realizar a apuração e redação dos textos em um período maior de tempo. Atualmente isso é mais raro. Quatro meses de pesquisa só têm os repórteres especiais e, ainda assim, normalmente não permanecem apenas com uma pauta. Há, no entanto, mais liberdade de expressão, essencial para o exercício do trabalho jornalístico.

Além disso, os veículos de comunicação muitas vezes utilizaram estratégias eficazes para a publicação de reportagens. Na série publicada no jornal $O$ Globo, por exemplo, cujo autor foi Carlos Chagas, a direção do jornal usou uma tática que deu certo: 113 dias de angústia-impedimento e morte de um presidente foi publicada em dois grandes veículos, em 1970 - além de O Globo, a matéria saiu também no jornal $O$ Estado de $S$. Paulo. Essa medida foi adotada como forma de impedir a censura, e foi sugestão do próprio Carlos Chagas, já que seria mais difícil censurar dois jornais de grande circulação - um no Rio de Janeiro e outro em São Paulo.

Ao longo da pesquisa foi possível constatar que, apesar da visibilidade que o Prêmio Esso proporcionou aos jornalistas, alguns deles resolveram, por diferentes motivos, desistir de trabalhar em redações. É o caso, por exemplo, de Luiz Fernando Emediato, que após levar o Prêmio em 1983, decidiu abrir uma editora e tornar-se escritor. Já Jorge Oliveira decidiu seguir a carreira de documentarista, por acreditar que assim poderia colocar a sua opinião de maneira mais direta em seus trabalhos. Outros jornalistas, como Getúlio Bittencourt, Ricardo Kotscho, Luiz Cláudio Cunha, Carlos Chagas e Norma Couri continuaram como repórteres, passando por diversos órgãos da imprensa.

Outra questão de grande importância, levantada pelos jornalistas entrevistados neste trabalho, diz respeito à pesquisa de campo. Para produzir reportagens de destaque, todos eles precisaram ir às ruas apurar, encontrar pessoas, observar, gastar às vezes três meses seguidos frente aos personagens, para conseguir uma história que valesse a pena ser contada. Hoje, graças à tecnologia de ponta, muitos 
jornalistas iniciantes prezam pela rapidez, mas parecem (e tendem) a "esquecer" que para se contar uma boa história é preciso observar, estar no local, ouvir diferentes pessoas, cruzar dados.

Diante das considerações apresentadas, pode-se constatar que um jornalismo de qualidade, expresso em grandes reportagens, só pode ser alcançado a partir da adoção de muitos dos princípios que foram identificados a partir da análise das vencedoras do Prêmio Esso de Jornalismo, tais como: presença do repórter no local; cruzamento de dados; e checagem de informações com diferentes fontes.

\section{CONCLUSÃO}

A presente pesquisa resgatou e analisou os bastidores de 12 reportagens vencedoras do Prêmio Esso entre 1964 e 1985. Para isso, foram estabelecidos três objetivos. Primeiro, o de identificar as principais técnicas de apuração jornalísticas usadas nas seis reportagens selecionadas entre as 21 vencedoras do Prêmio Esso no período pesquisado. O segundo, com base nos temas abordados, foi o de mostrar como a pauta foi elaborada e quais as dificuldades para a publicação das matérias, já que, durante parte do regime militar, os censores se instalaram dentro das redações. E, por último, verificar se a produção dessas reportagens mudou os rumos profissionais dos seus autores.

Dentre as limitações encontradas para a realização deste trabalho, é relevante mencionar a dificuldade em localizar diversos jornalistas vencedores do Prêmio Esso, que não moram em Brasília (durante a preparação do trabalho, foram enviados e-mails a alguns deles). Das doze entrevistas, seis foram realizadas via e-mail (José Marqueiz, Norma Couri, Getúlio Bittencourt, Luiz Fernando Emediato, José Maria Mayrink e Vital Battaglia) e quatro pessoalmente (Ricardo Kotscho, Carlos Chagas, Luiz Cláudio Cunha e Jorge Oliveira). Algumas informações também foram recuperadas a partir de depoimentos já publicados dos autores das reportagens. É o caso dos jornalistas Fritz Utzeri e Amicucci Gallo. É importante citar também que dos 21 jornalistas vencedores do Prêmio Esso de Jornalismo três deles não estão vivos.

No eixo Rio-São Paulo, uma vencedora do Esso que merece destaque é Exclusivo: fala Figueiredo, feita pelos jornalistas Getúlio Bittencourt e Haroldo Cerqueira Lima. A matéria, publicada em 1978 na Folha de S.Paulo, foi a primeira reportagem política premiada após anos de regime militar e censura: tratava daquele que seria o sucessor do então presidente Ernesto Geisel - o general João Baptista de Figueiredo. A conversa dos jornalistas com Figueiredo durou mais de uma hora e meia. De acordo com os depoimentos dos repórteres, durante todo o tempo, nenhum deles tomou nota ou gravou a entrevista. Isso não impediu a reprodução, quase que na íntegra, do que havia sido dito na entrevista, e revelou o perfil daquele que seria o futuro presidente do país.

A excelência dessa e de outras reportagens deve ser resgatada, em pesquisas posteriores a esta, a fim de que a nova geração de jornalistas possa não só lembrar, mas continuar a produzir matérias de 
qualidade. Mesmo com a pressa existente nas redações e conhecendo os processos de apuração usados nas reportagens vencedoras do Prêmio Esso, é possível também aprimorar o jeito de se fazer jornalismo nos dias de hoje. Em vez de o jornalista prezar apenas pelo furo, é fundamental que ele valorize também o rigor na hora da apuração. Somente desta maneira será possível produzir matérias que, de alguma forma, colaborem para a construção da realidade do país, quer seja mostrando suas contradições, quer seja apontando soluções para problemas - como aconteceu na reportagem de José Maria Mayrink, Receita para São Paulo.

Com o trabalho, vale destacar que mesmo tendo censores instalados nas redações os grandes jornais continuaram a publicar reportagens importantes para a construção da realidade brasileira durante a ditadura militar. Foi o caso, por exemplo, das matérias da equipe da Veja nos anos de 1979 e 1983. No fim da década de 70, a investigação do repórter Luiz Cláudio Cunha e do fotógrafo João Batista Scalco foi essencial para a elucidação de uma das histórias de seqüestros de exilados. A cobertura da revista contribuiu para o esclarecimento da história de uruguaios presos no Brasil, que ganhou repercussão internacional. Quatro anos depois, a equipe de Veja voltaria a produzir outra reportagem essencial para o desfecho de outro caso: o de Alexandre von Baumgarten, jornalista assassinado em outubro de 1982. Após meses de apuração e medo constante, os jornalistas publicaram a matéria mostrando que, ao contrário do que muitos imaginavam, a morte de Baumgarten "não fora fruto de um suposto afogamento no mar" (BELOCH e FAGUNDES, 2006, p. 95).

Por meio das entrevistas feitas nesta pesquisa, foi possível constatar que, mesmo diante do autoritarismo presente no Brasil durante os 21 anos de regime militar, as matérias não encontraram grandes dificuldades na publicação, ainda que algumas delas tratassem de denunciar e revelar as entranhas do poder naqueles anos - Ricardo Kotscho disse que estava pesquisando hábitos da nova capital, quando na verdade procurava por mordomias; José Marqueiz foi esquecido no Norte do Mato Grosso pela Polícia Federal, que confundiu um avião dele com o de um dos indigenistas; os militares acreditaram que Carlos Chagas não falaria mal deles, por ter sido porta-voz da Presidência; e Figueiredo achou que o fato de os repórteres da Folha de S.Paulo Getúlio Bittencourt e Haroldo Cerqueira Lima não terem gravado a entrevista os impediria de publicar declarações textuais. Isso comprova o que Dines (1996, p. 135) já havia dito sobre a censura - "Intrinsecamente falha, superável e pouco inteligente". 


\section{REFERÊNCIAS BIBLIOGRÁFICAS}

ABREU, Alzira Alves de (org.). A Imprensa em transição. Rio de Janeiro: Editora Fundação Getúlio Vargas, 1996.

, LATTMAN-WELTMAN, Fernando e ROCHA, Dora (orgs). Eles mudaram a imprensa. Rio de Janeiro: Editora FGV, 2003.

AQUINO, Maria Aparecida de. Censura, Imprensa e Estado Autoritário (1968 - 1978): o exercício cotidiano da dominação e da resistência: O Estado de S. Paulo e Movimento. Bauru: EDUSC, 1999.

BELOCH, Israel e FAGUNDES, Laura Reis (org). Uma história escrita por vencedores - 50 anos do Prêmio Esso de Jornalismo. Rio de Janeiro: Memória Brasil, 2006.

DINES, Alberto. O papel do jornal: uma releitura. 6. ed. São Paulo: Summus, 1996.

DUARTE, Jorge e BARROS, Antonio (orgs.). Métodos e Técnicas de Pesquisa em Comunicação. São Paulo: Atlas S.A, 2005.

FAUSTO, Boris. História do Brasil. 10. ed. - São Paulo: Editora da Universidade de São Paulo, 2002.

FERNANDES Jr., Florestan, DINES, Alberto e SALOMÃO, Nelma (org). Histórias do Poder: 100 anos de política no Brasil, vol. 1: Militares, Igreja e sociedade civil. São Paulo: Ed. 34, 2000.

GASPARI, Elio. A ditadura envergonhada. São Paulo: Companhia das Letras, 2002.

GRAMACHO, Wladimir. "Jornalismo Investigativo", in SEABRA, Roberto e SOUSA, Vivaldo de (org.). Jornalismo Político - Teoria, História e Técnicas. Rio de Janeiro: Editora Record, 2006.

KOTSCHO, Ricardo. Do Golpe ao Planalto: Uma vida de repórter. São Paulo: Companhia das Letras, 2006.

KOVACH, Bill e ROSENSTIEL, Tom. Os Elementos do Jornalismo. Tradução de São Paulo: Geração Editorial, 2003

KUCINSKI, Bernardo. A síndrome da antena parabólica: ética no jornalismo brasileiro. São Paulo: Fundação Perseu Abramo, 1998.

LOPES, Dirceu Fernandes, e PROENÇA, José Luiz (Org.) Jornalismo investigativo. São Paulo: Publisher Brasil, 2003.

MACEDO, Francisco. Jornalismo investigativo e grandes reportagens durante os 20 anos do regime militar. Trabalho elaborado para o IV PIC (Programa de Iniciação Científica) do UniCEUB, 2006.

MIRANDA, Guilherme. (Org.) Prêmio Esso: 40 anos do melhor em jornalismo. Rio de Janeiro: Memória: Relume Dumará, 1995

MOLICA, Fernando (org.). 10 Reportagens que abalaram a ditadura. Rio de Janeiro: Editora Record, 2005. (org). 50 anos de crime: reportagens policiais. Rio de Janeiro: Editora Record, 2007 
SKIDMORE, Thomas E. Uma história do Brasil. São Paulo: Paz e Terra, 1998.

TRAQUINA, Nelson (Org.). Jornalismo: questões, teorias e “estórias”. 2. ed. Lisboa, 1999. 